\title{
Synthetic strategies of phosphonodepsipeptides
}

\author{
Jiaxi Xu
}

\author{
Review \\ Address: \\ State Key Laboratory of Chemical Resource Engineering, Department \\ of Organic Chemistry, College of Chemistry, Beijing University of \\ Chemical Technology, Beijing 100029, People's Republic of China \\ Email: \\ Jiaxi Xu - jxxu@mail.buct.edu.cn

\section{Keywords:} \\ alkylation; mimetic; multicomponent condensation; peptide; \\ phosphonopeptide; phosphonodepsipeptide; phosphonylation
} \\ Open Access}

Beilstein J. Org. Chem. 2021, 17, 461-484.

https://doi.org/10.3762/bjoc.17.41

Received: 17 November 2020

Accepted: 02 February 2021

Published: 16 February 2021

Associate Editor: N. Sewald

(C) 2021 Xu; licensee Beilstein-Institut.

License and terms: see end of document.

\begin{abstract}
Phosphonodepsipeptides are phosphorus analogues of depsipeptides and phosphonate-linked analogues of naturally occurring peptides. They are more stable than phosphonopeptides and have been widely applied as enzyme inhibitors, haptens for the production of antibodies, biological agents, and prodrugs. The synthetic strategies towards phosphonodepsipeptides are reviewed, including the phosphonylation of hydroxy esters with phosphonochloridates, the condensation of phosphonic monoesters and hydroxy esters, the alkylation of phosphonic monoesters with 1-(alkoxycarbonyl)alkyl halides or sulfonates, multicomponent condensation of amides, aldehydes, and dichlorophosphites followed by alcoholysis with hydroxy esters, the phosphinylation of hydroxy esters with phosphonochloridites followed by oxidation, and the carbene insertion of $N$-protected amino acids with 1-diazoalkylphosphonates. This review includes the synthesis of $\alpha$-, $\beta$-, and $\gamma$-phosphonodepsipeptides and phosphonodepsipeptides with C-1-hydroxyalkylphosphonic acids.
\end{abstract}

\section{Introduction}

Both, phosphonopeptides and phosphonodepsipeptides are phosphorus analogues of peptides [1-5]. The phosphonopeptides are peptides with a phosphonamidate bond instead of an amide bond whereas the phosphonodepsipeptides are peptides with a phosphonate linkage instead of an amide. Phosphonodepsipeptides are structurally close analogues of depsipeptides (Figure 1). In general, phosphonodepsipeptides are more stable than the corresponding phosphonopeptides because the phosphonate bond is more inert than a phopshonamidate bond. Phosphonodepsipeptides are widely used as enzyme inhibitors [6-10], haptens for inducing catalytic antibodies [11,12], and produgs $[8,9,13]$. They have potential applications as antibiotics [14], antimicrobials [15], antimalarials [16], antitumor agents [17], and medicinal agents [18]. Thus, much attention has been paid to the synthesis of phosphonodepsipeptides.

To date, diverse synthetic strategies of phosphonodepsipeptides 1 have been developed. The strategies comprise the phosphonylation of hydroxy esters 2 with $N$-protected aminoalkylphosphonochloridates 3 (method I), reactions of $N$-protected aminoalkylphosphonic monoesters 4 with hydroxy esters 2 (method II) or with 1-(alkoxycarbonyl)alkyl halides or 


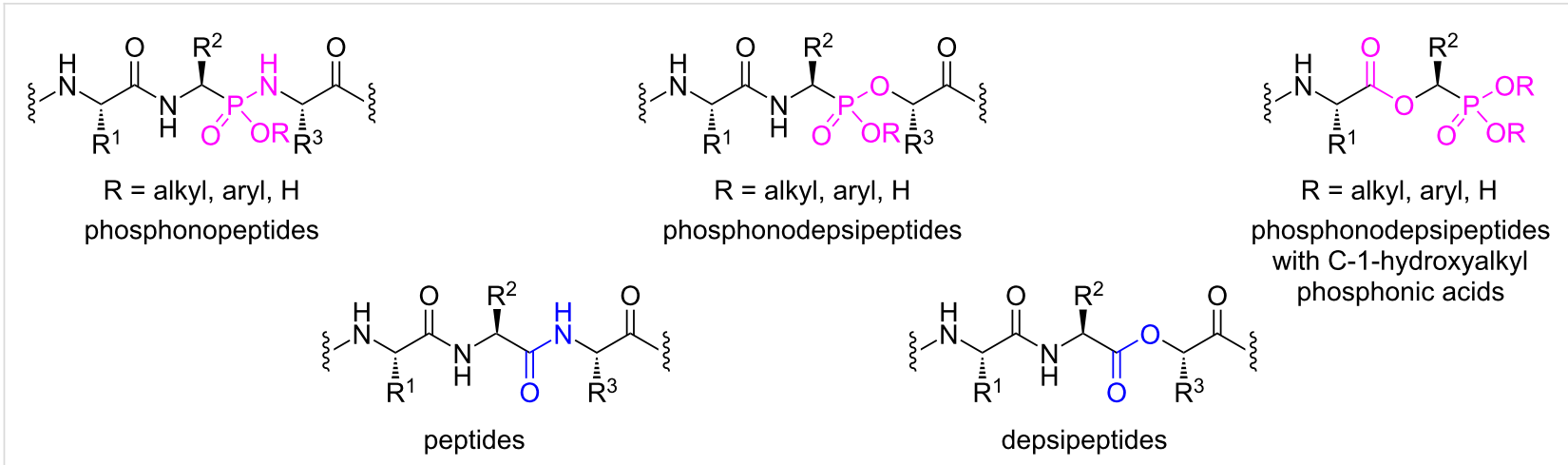

Figure 1: Phosphonopeptides, phosphonodepsipeptides, peptides, and depsipeptides.

sulfonates 5 (method III), pseudo-four-component condensations (method IV), and the phosphinylation of hydroxy esters 2 with $\mathrm{N}$-protected aminoalkylphosphonochloridites $\mathbf{9}$ followed by oxidation (method V) (Figure 2). This review focuses on the synthetic methods of phosphonodepsipeptides and phosphonodepsipeptides with C-1-hydroxyalkylphosphonic acids, excluding peptides with side-chain phosphonic acids.

\section{Review}

\section{Synthesis of phosphonodepsipeptides via the phosphonylation of hydroxy esters with phosphonochloridates}

The phosphonylation of hydroxy esters 2 with alkyl $\mathrm{N}$-protected aminoalkylphosphonochloridates $\mathbf{3}$ is a general and widely applied method for the synthesis of $\alpha$-, $\beta$-, and $\gamma$-phos- phonodepsipeptides $\mathbf{1}$. The $N$-protected aminoalkylphosphonic monomethyl/ethyl esters are very useful materials for the preparation of $N$-protected aminoalkylphosphonochloridates 3 . $N$-Protected aminoalkylphosphonic diaryl esters should be converted into the corresponding monomethyl/ethyl esters via transesterification and selective hydrolysis.

\section{Synthesis of $\alpha$-phosphonodepsipeptides}

In 1987, a series of phosphonodepsidipeptides 10 was synthesized as phosphorus analogues of peptides and evaluated as inhibitors of leucine aminopeptidase from porcine kidney and two compounds, i.e., 10e and $\mathbf{1 0 h}(\mathrm{R}=$ isobutyl, benzyl) were modest inhibitors. The synthesis started from diphenyl $\mathrm{N}$-Cbz1-aminoalkylphosphonates 11 (Scheme 1). They were transformed to dimethyl esters via transesterification and further to monomethyl esters 12 via basic hydrolysis. After chlorination

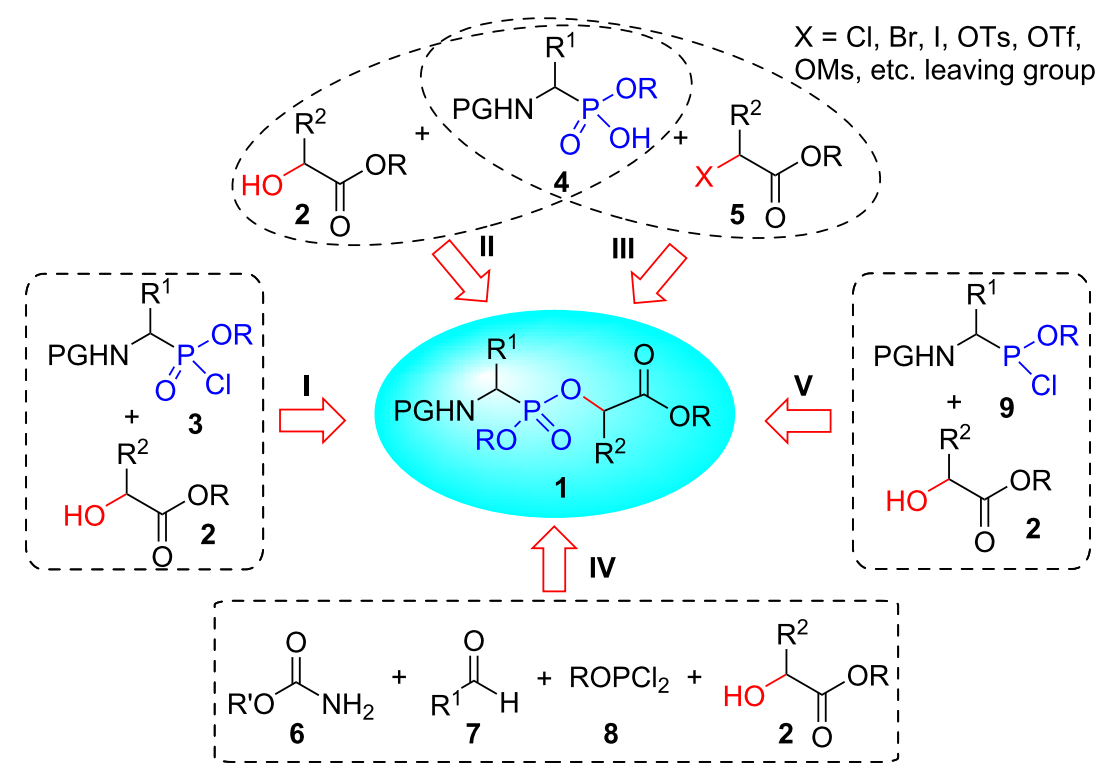

Figure 2: The diverse strategies for phosphonodepsipeptide synthesis. 


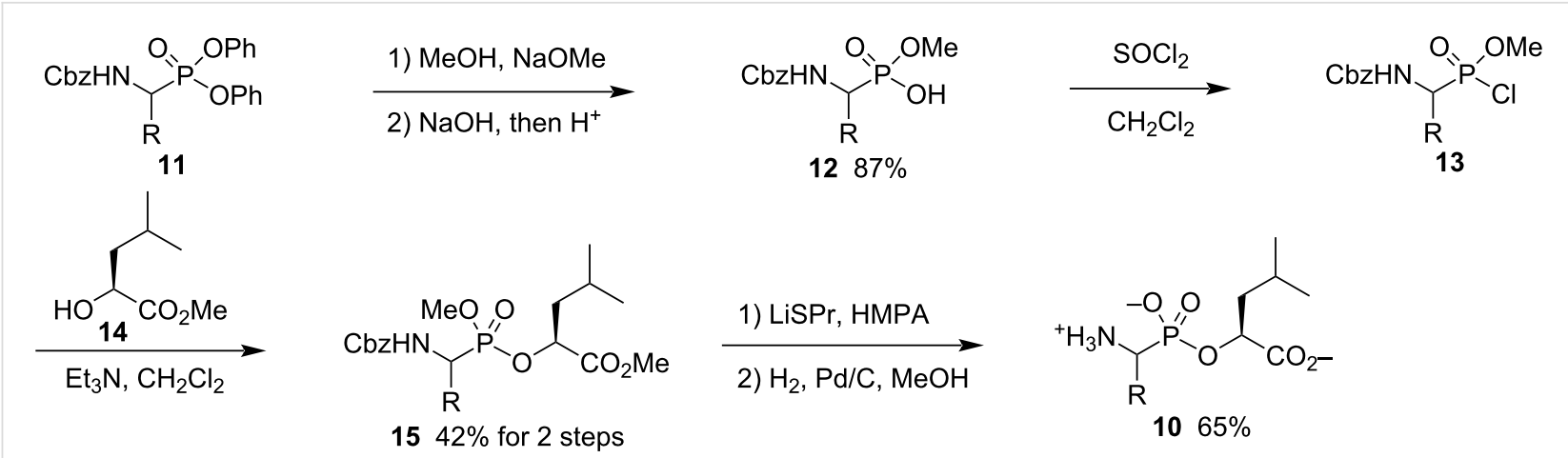

a: $R=H, \mathbf{b}: R=M e, \mathbf{c}: R=E t, \mathbf{d}: R=i \operatorname{Pr}, \mathbf{e}: R=i B u, \mathbf{f}: R=A m, \mathbf{g}: R=$ heptyl, $\mathbf{h}: R=B n$

Scheme 1: Synthesis of $\alpha$-phosphonodepsidipeptides as inhibitors of leucine aminopeptidase.

with thionyl chloride, the monomethyl esters $\mathbf{1 2}$ were converted into $\mathrm{N}$-Cbz-1-aminoalkylphosphonochloridates $\mathbf{1 3}$, which were further coupled with methyl $(S)$-2-hydroxy-4methylpentanoate (14), affording the protected phosphonodepsidipeptides 15. Finally, after deprotection the free phosphonodepsidipeptides 10 were obtained [19].

The disodium salts of the trans and cis isomers of 2-hydroxy-2oxo-3-[(phenoxyacetyl)amino]-1,2-oxaphosphorinane-6carboxylic acid (16, Figure 3 ) were prepared and evaluated as inhibitors of the zinc-containing $\beta$-lactamase II from $B$. cereus. However, neither stereoisomer had any significant activity [6].<smiles>O=C(COc1ccccc1)NC1CCC(C(=O)O)OP1(=O)O</smiles>

Figure 3: Structure of 2-hydroxy-2-oxo-3-[(phenoxyacetyl)amino]-1,2oxaphosphorinane-6-carboxylic acid (16).

The phosphonodepsidipeptide $\mathbf{1 7}$ was synthesized via the coupling of methyl $N$-Cbz-1-aminoethylphosphonochloridate (13b) generated from phosphonic monomethyl ester 12b and methyl (S)-2-hydroxy-3-phenylpropanoate (18) followed by hydrogenolysis. It was further coupled to cyclen to afford various cyclen-containing phosphonodepsipeptides as inhibitors of carboxypeptidase A (Scheme 2) [20].

VanX is a $\mathrm{Zn}(\mathrm{II})$-dependent D-Ala-D-Ala dipeptidase. To prepare novel inhibitors of VanX, $N$-[(1-aminoethyl)hydroxyphosphinyl]-D-lactate (20a), and $\{S$-[(aminoethyl)hydroxyphosphinyl]thio acetic acid (20b) were synthesized via coupling of the methyl $\mathrm{N}$-Cbz-protected 1-aminoethylphospho-
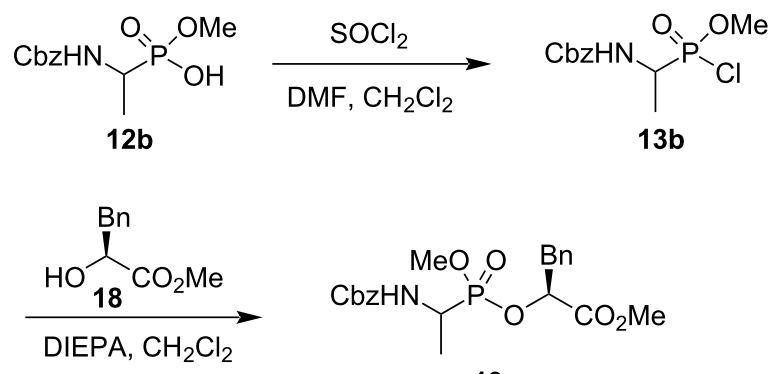

19

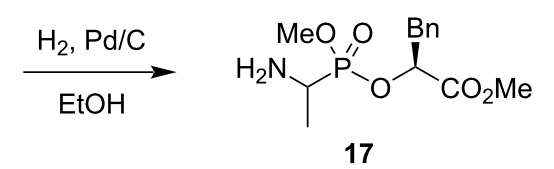

Scheme 2: Synthesis of $\alpha$-phosphonodepsidipeptide 17 as coupling partner for cyclen-containing phosphonodepsipeptides as inhibitors of carboxypeptidase A.

nochloridate 13b with methyl D-lactate (22a) and methyl mercaptoacetate (22b), respectively, followed by a basic hydrolysis and hydrogenolysis. The bioassay results indicated that the phosphonothiodepsidipeptide 20b did not inhibit VanX (Scheme 3) [21].

It was discovered that the enzymatic activity of VanX was inhibited competitively by phosphonodepsidipeptide 2-\{[(1aminoethyl)(hydroxy)phosphoryl]oxy \} propanoic acid (25b). Seven phosphonodepsidipeptides $\mathbf{2 5}$ as analogues of D-Ala-DAla with various substituents were prepared through the reaction of methyl $N$-Cbz 1-aminoethylphosphonochloridate (13b) with different benzyl 1-hydroxyalkanoates $\mathbf{2 6}$ followed by hydrogenolysis and hydrolysis. The bioassay results indicated that six out of the seven synthetic phosphonodepsipeptides 25 inhibited VanX with $\mathrm{IC}_{50}$ values ranging from 0.48 to $8.21 \mathrm{mM}$ (Scheme 4) [7]. 


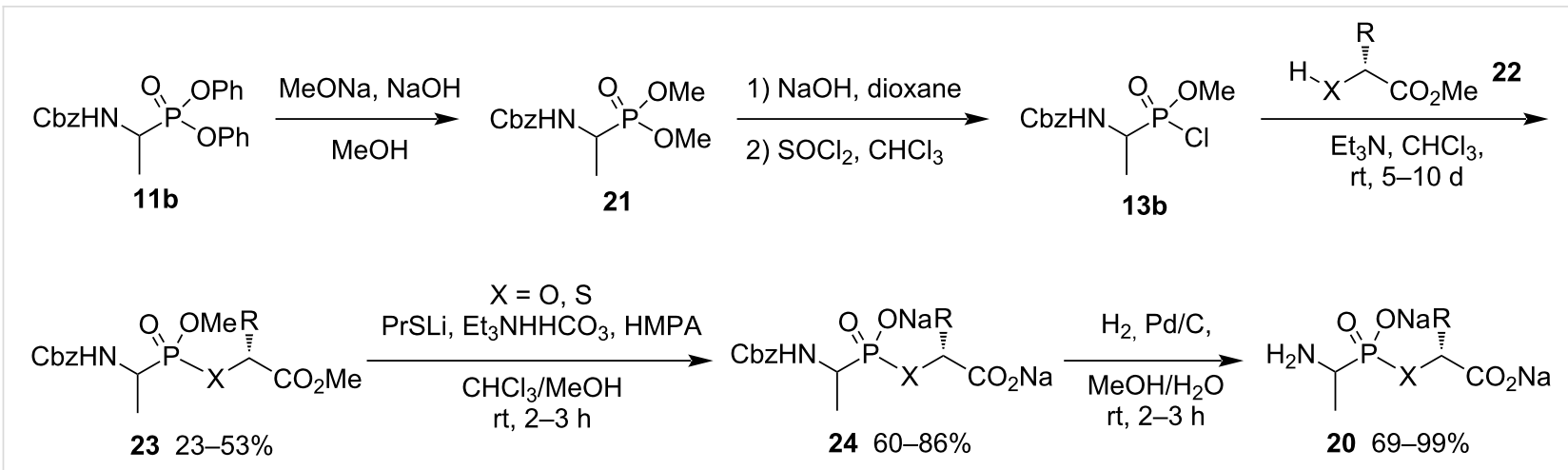

a: $X=O, R=M e ; b: X=S, R=H$

Scheme 3: Synthesis of $\alpha$-phosphonodepsidipeptides containing enantiopure hydroxy ester as VanX inhibitors.

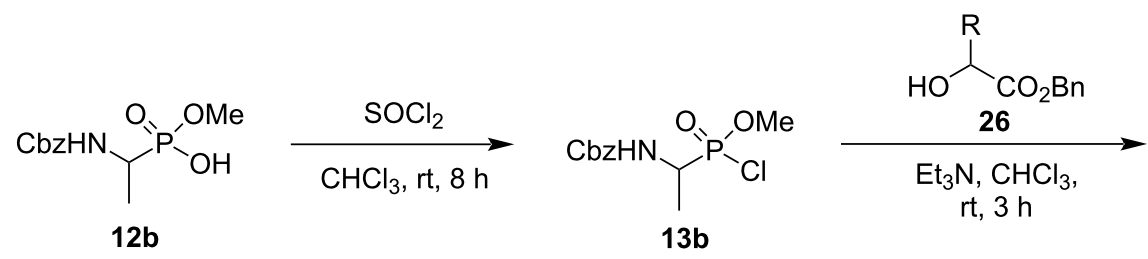<smiles>[R]C(OP(=O)(OC)C(C)NC(=O)OCc1ccccc1)C(=O)OCc1ccccc1</smiles>

$2748-61 \%$
1) $\mathrm{H}_{2}, \mathrm{Pd} / \mathrm{C}$ $\mathrm{MeOH}, 3 \mathrm{~h}$
2) $\mathrm{LiOH}, \mathrm{MeOH}$
rt, $2 \mathrm{~d}$
3) $\mathrm{HCl}$<smiles>[R]C(OP(=O)(O)C(C)N)C(=O)O</smiles>

$2550-87 \%$

a: $\mathrm{R}=\mathrm{H}, \mathbf{b}: \mathrm{R}=\mathrm{Me}, \mathbf{c}: \mathrm{R}=\mathrm{iPr}, \mathbf{d}: \mathrm{R}=\mathrm{iBu}, \mathbf{e}: \mathrm{R}=\mathrm{s}-\mathrm{Bu}, \mathbf{f}: \mathrm{R}=\mathrm{Bn}, \mathbf{g}: \mathrm{R}=\mathrm{CH}_{2} \mathrm{CH}_{2} \mathrm{CO}_{2} \mathrm{H}$

Scheme 4: Synthesis of $\alpha$-phosphonodepsidipeptides as VanX inhibitors.

Two optically active phosphonodepsidipeptides $\mathbf{2 8}$ were prepared and investigated as VanX inhibitors. The racemic $N-\mathrm{Cbz}$ 1-aminoethylphosphonic acid (29) was separated by chemical resolution with quinine, affording the $(S)-N$-Cbz-1-aminoethylphosphonic acid $((S)$-29), which was transformed to the corresponding phosphonochloridate and further reacted with benzyl $(R)$-lactate $((R)$-26b) or benzyl $(R)$-2-phenyllactate $((R)$-26f $)$.
The optically active phosphonodepsidipeptides $\mathbf{2 8}$ were obtained after hydrogenolysis and tested for their biological activity (Scheme 5) [22].

The phosphonodepsidipeptides $\mathbf{3 1}$ were synthesized by the esterification of $\mathrm{N}$-Cbz-aminoalkylphosphonic acids $\mathbf{3 2}$ and 4-nitrobenyl 2-hydroxyalkanoates $\mathbf{3 3}$ in the presence of $\mathrm{SOCl}_{2}$<smiles>CCO[Na]</smiles><smiles>[R]C(OP(=O)(O)C([R])NC(=O)NC(=O)OCc1ccccc1)C(=O)OCc1ccccc1</smiles>

30

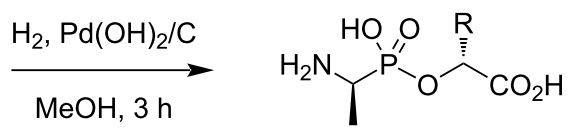

$2830-56 \%$ for 3 steps 
in DMF. This was an efficient coupling reaction for the synthesis of phosphonodepsipeptides from $\mathrm{N}$-protected phosphonic acids and hydroxy esters. The phosphonodepsidipeptide $\mathbf{3 1}$ $\left(\mathrm{R}^{1}=\mathrm{R}^{2}=\mathrm{H}\right.$, Scheme 6) was converted to the free phosphonodepsidipeptide $\mathbf{3 4}$ in $80 \%$ yield and the $N$-Cbz-phosphonodepsidipeptide 35 in $85 \%$ yield, respectively, via hydrogenolysis and basic hydrolysis, respectively (Scheme 6) [23]. The method actually is a convenient and direct method to synthesize phosphonodepsipeptides from $N$-protected phosphonic acids and hydroxy esters through phosphonochloridates as in situ-generated intermediates.

To prepare an antigen to induce monoclonal catalytic antibodies capable of catalyzing peptide-bond formation reactions, the phosphonodepsidipeptide $\mathbf{3 9}$ was synthesized via the coupling of the hydroxy analog of tryptophan amide with 4-nitrobenzyl ( $R$ )- $N$-Fmoc 1-amino(cyclohexyl)methylphosphonochloridate (38), which was prepared from diethyl $(R)-N$-Fmoc 1-amino(cyclohexyl)methylphosphonate (36) via a selective basic hydrolysis, chlorination, esterification with 4-nitrobenzyl alcohol, selective basic hydrolysis, and chlorination. After the treatment of compound 39 with piperidine, the $N$-terminal free dipeptide was obtained and acylated with hexanedioic anhydride to afford the designed hapten $\mathbf{4 0}$ (Scheme 7) [11].

Phosphonodepsioctapeptide $\mathbf{4 1}$ was prepared as a variation of the partial sequence of a gene product of erb B-2. Two different hydroxypeptide esters $\mathbf{4 6}$ were first prepared and successful-

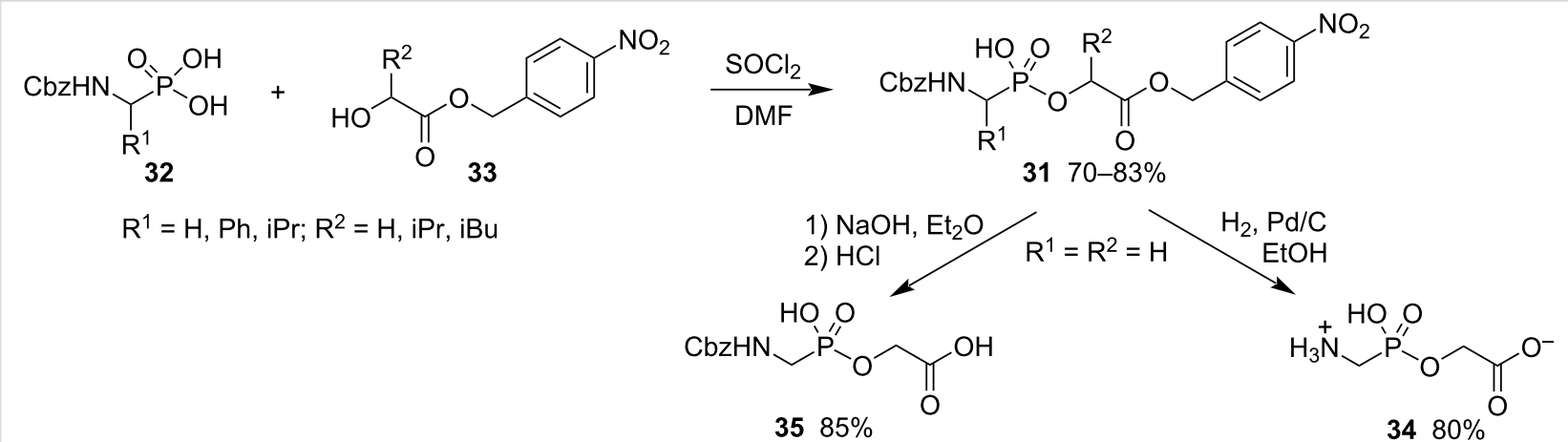

Scheme 6: The synthesis of phosphonodepsipeptides through a thionyl chloride-catalyzed esterification of $N$-Cbz aminoalkylphosphonic acids 32 and 4-nitrobenyl 2-hydroxyalkanoates 33.

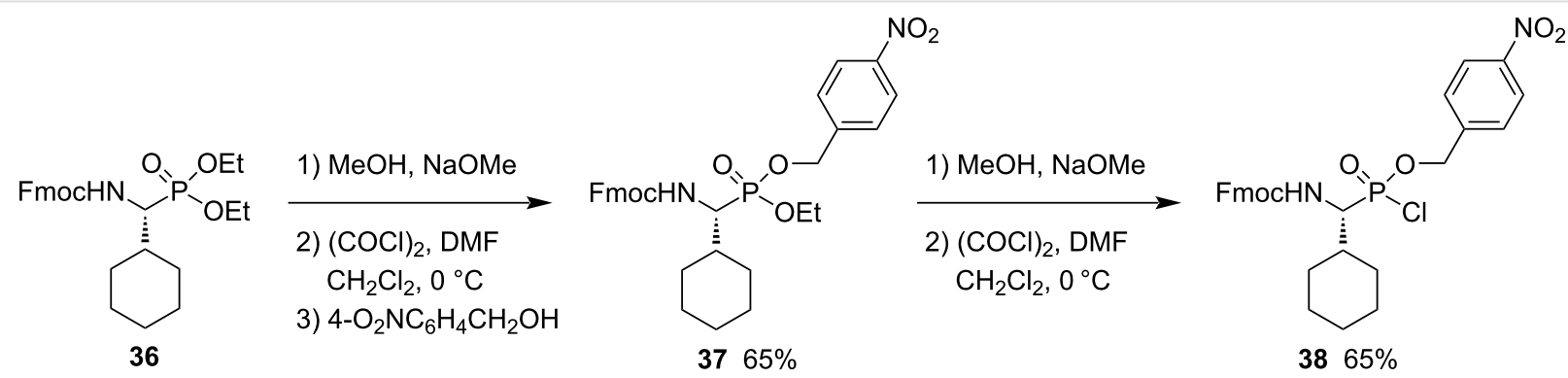

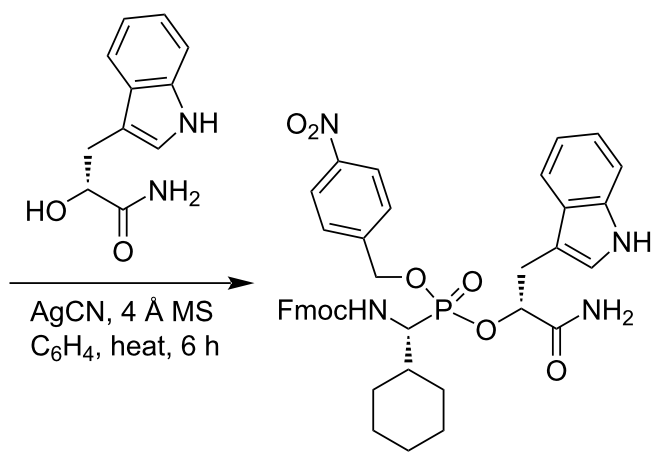

$3918-32 \%$ for 3 steps

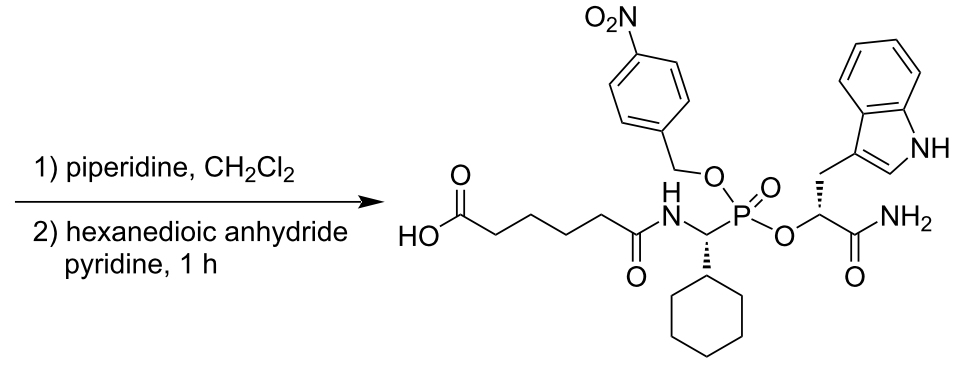

$4072 \%$ 
ly coupled with methyl $\mathrm{N}$-Cbz-1-aminoethylphosphonochloridate $((R)-\mathbf{1 3 b})$ by use of their magnesium salts because the direct coupling of the hydroxypeptide esters $\mathbf{4 6}$ with the phosphonochloridate $(R)$-13b failed. The magnesium salts were in situ generated from the hydroxypeptide esters $\mathbf{4 6}$ with a Grignard reagent (Scheme 8) [24].

To minimize the side reactions of 1-aminoalkylphosphonochloridates, a convenient method for the synthesis of phosphonodepsipeptides was described. The $\mathrm{N}$-Cbz-protected 2-aminoalkylphosphinates $\mathbf{5 0}$ were converted to their trimethylsilyl phosphonites 52 through the treatment with bis(trimethylsilyl)acetamide (51). The phosphonites 52 were then oxidized with $\mathrm{CCl}_{4}$ to generate the corresponding phosphonochloridates 53 as intermediates, which reacted with hydroxy esters $\mathbf{5 4}$ and $\mathbf{5 5}$ to give rise to the desired phosphonodepsipeptides $\mathbf{5 6}$ and
57, respectively. The oxidative activation was carried out in the presence of alcohols as nucleophiles so that stoichiometric formation of the phosphonochloridate was avoided and side reactions were minimized (Scheme 9) [25]. The current chlorination is a mild and neutral method for the preparation of phosphonochloridates.

Eleven phosphonodepsitetrapeptides $\mathbf{5 8}$ were synthesized and evaluated as inhibitors of the aspartic peptidase pepsin. The synthesis started from methyl $(R)-N$-Cbz-1-amino-2phenylethylphosphinate (59). In wet acetonitrile compound 59 was oxidized into the corresponding phosphonic monomethyl ester $(R)-\mathbf{1 2 h}$ with carbon tetrachloride due to hydrolysis of the phophonochloridate intermediate. The phosphonic monomethyl ester $(R)-\mathbf{1 2 h}$ was further chlorinated to the phosphonochloridate $(R)-\mathbf{1 3 h}$, which was coupled with 3-(pyridin-4-yl)propyl

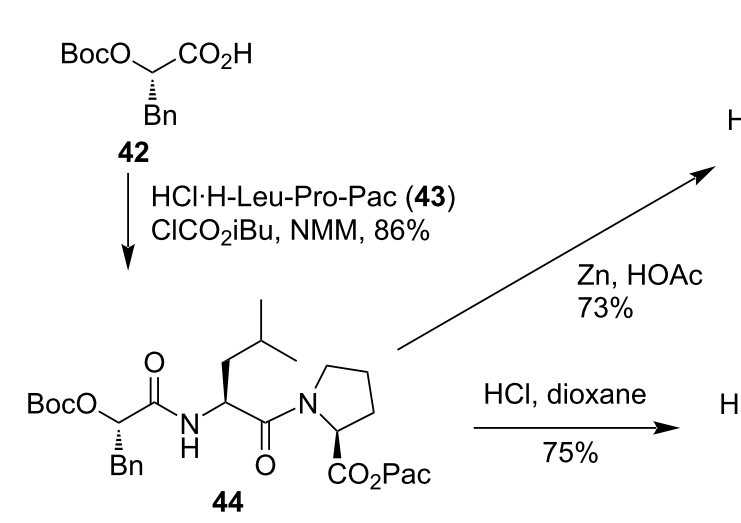

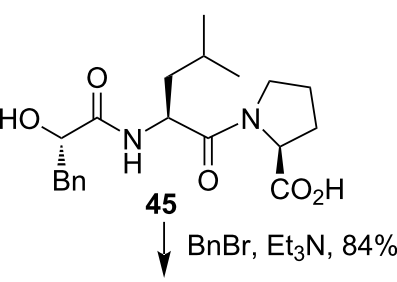<smiles></smiles><smiles>CC(C)NC(C)P(=O)(Cl)OC(C)(C)C(C)(C)C</smiles>

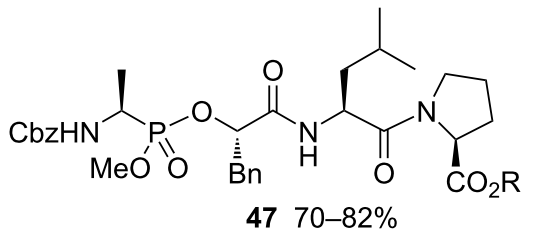

1) $\mathrm{H}_{2}, \mathrm{Pd} / \mathrm{C}, \mathrm{HOAc}$ (followed by $\mathrm{HCl}$ for $\mathrm{R}=\mathrm{Pac}$ )

2) Cbz-Phe-Gly-Ser(Bn)-Leu-ONSu

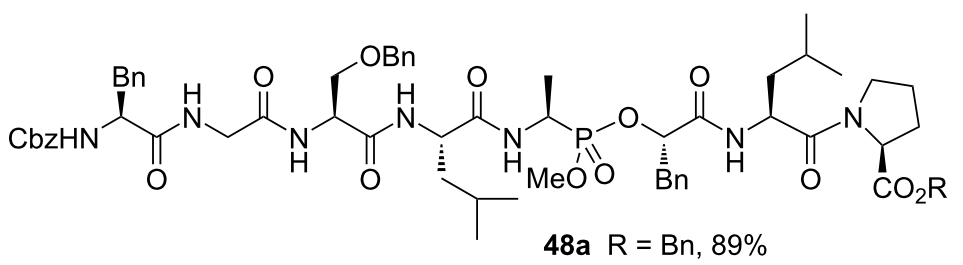
1) Nal, butan-2-one, $79 \%$ 2) $\mathrm{H}_{2}, \mathrm{Pd} / \mathrm{C}, 100 \%$<smiles>[CH]C(C)C[C@H](NC(=O)[C@H](CO)NC(=O)CNC(=O)[C@H](N)Cc1ccccc1)C(=O)N[C@@H](C)P(=O)(O)O[C@@H](Cc1ccccc1)C(=O)N[C@@H](CC(C)C)C(=O)N1CCC[C@H]1C(=O)O</smiles> 


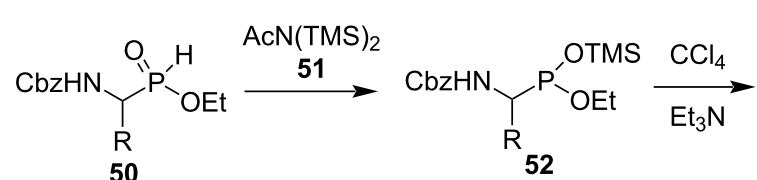<smiles>[R]C(NC(C)C)P(=O)(Cl)OCC</smiles>

53

56 60\%<smiles>COC(=O)C(C)NC(=O)C(O)CC(C)C</smiles><smiles>CCC(C)C(=O)OP(=O)(OCC(C)C)C(Cc1ccccc1)N[C@@H](C)C(=O)OC</smiles>

Scheme 9: Synthesis of phosphonodepsipeptides via an in situ-generated phosphonochloridate.
(S)-2-hydroxy-3-phenylpropanoate (60) to give rise to the phosphonodepsidipeptide 61. The phosphonodepsidipeptide $\mathbf{6 1}$ was also obtained directly by the oxidation of the phosphinate $\mathbf{5 9}$ with carbon tetrachloride in the presence of the hydroxy ester 60. After hydrogenolysis of $\mathbf{6 1}$ and coupling with various $N$-protected dipeptides 62, the $N$-protected phosphonodepsitetrapeptides 63 were obtained and further transformed to the $N$-protected phosphonodepsipeptide ester lithium salts 58 after aminolysis with tertiary butylamine and treatment with Dowex$\mathrm{Li}^{+}$(Scheme 10) [26].

\section{Synthesis of $\beta$-phosphonodepsipeptides}

To develop iminocyclitol-based small molecule libraries against a bacterial TGase, an iminocyclitol was conjugated with a pyrophosphate mimic. After in situ screening, the first potent iminocyclitol-based inhibitor against bacterial TGases was efficiently developed [27].

The synthesis of $N$-pyrrolidine-derived $\beta$-phosphonodepsipeptides 64 is shown in Scheme 11. First, dibenzyl allylphosphonate (65) was converted to benzyl allylphosphonochloridate

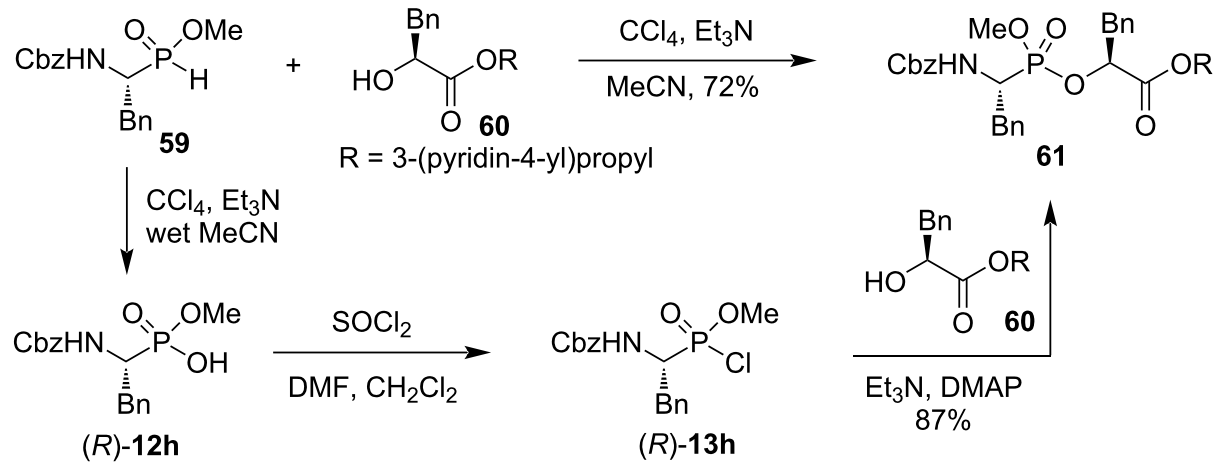

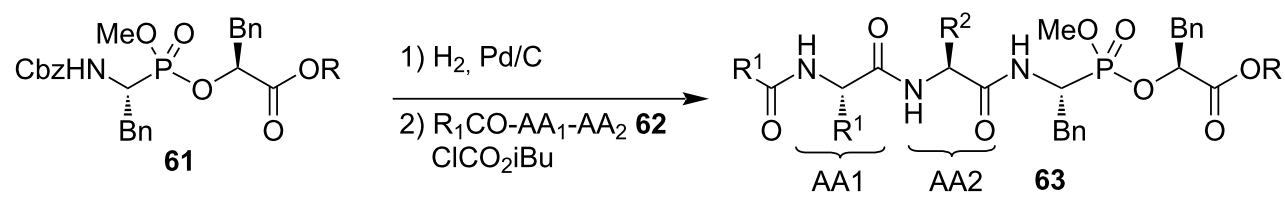<smiles>[R1]C(=O)NC([R1])C(=O)NC([R])C(=O)NC(Cc1ccccc1)P(=O)(O[Ga])OC(Cc1ccncc1)C(=O)OCCCc1ccncc1</smiles>

$5820-40 \%$

R¹CO-AA1-AA2 = CbzGlyPro, CbzGly-D-Ala, Cbz-D-AlaGly, CbzSarGly, CbzGlyGly, CbzGlylle, CbzPheGly, CbzAlaGly, CbzGlyAla, CbaAlaAla, MocGlyGly 


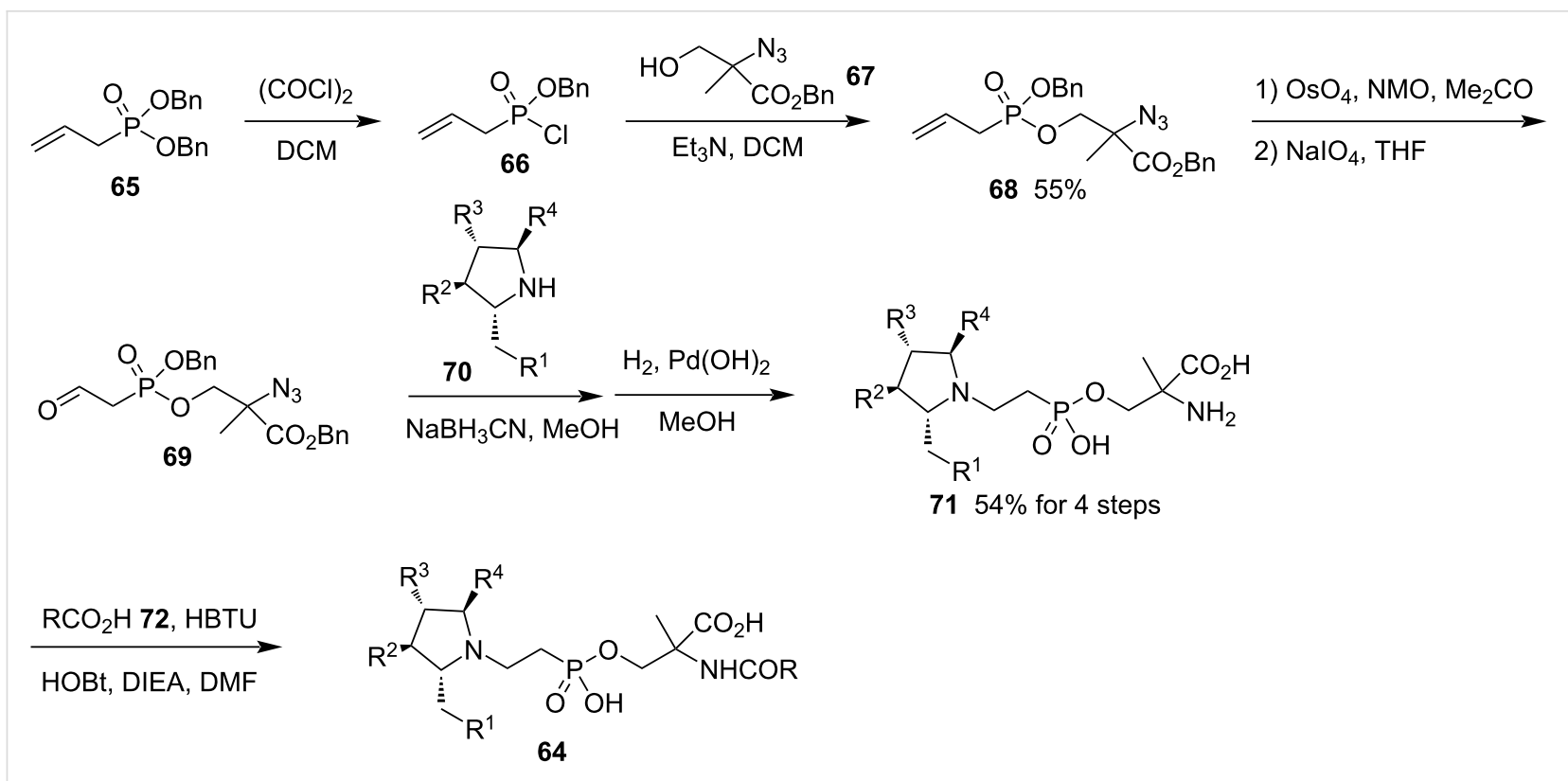

Scheme 11: Synthesis of a $\beta$-phosphonodepsidipeptide library 64.

(66), which was then coupled with benzyl 2-azido-3-hydroxy-2methylpropanoate (67) producing benzyl [allyl(benzyloxy)phosphoryl)oxy]propanoate (68). After the dihydroxylation with osmium tetroxide and oxidation with sodium periodate, benzyl 2-azido-3-(((benzyloxy)(2-oxoethyl)phosphoryl)oxy)-2-methylpropanoate (69) was obtained. The latter was further transformed to the final phosphonodepsipeptide library $\mathbf{6 4}$ after the reductive amination with pyrrolidine derivatives $\mathbf{7 0}$ and acyl- ation with a library of carboxylic acids $\mathbf{7 2}$ in the presence of coupling reagents (Scheme 11) [27].

Alternatively, the 1,3-protected glycerol $\mathbf{7 3}$ was first converted into various 2,3-protected glycerols $\mathbf{7 4}$, which were further transformed to methyl 2-alkoxy-3-hydroxypropanoates $\mathbf{7 5}$. Following a similar strategy as above, another library of phosphonodepsipeptides $\mathbf{7 8}$ was prepared (Scheme 12) [27].
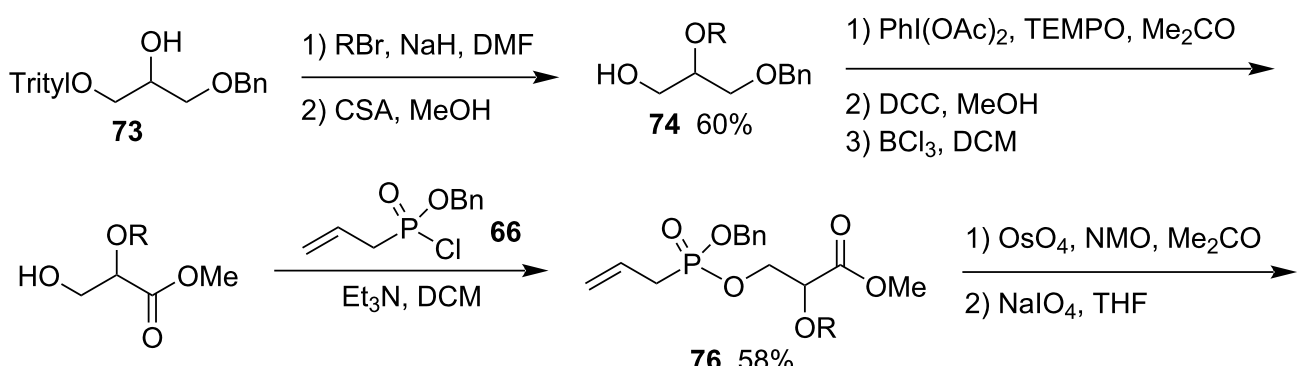

$7547 \%$ for 3 steps

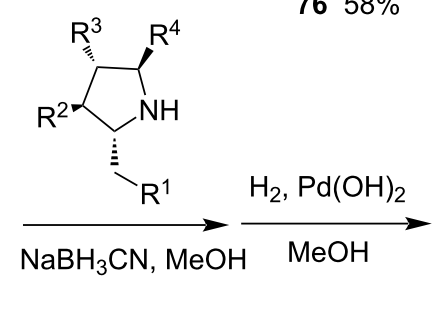

77<smiles>[R]C[C@H]1C([R])C([R])C([R1])N1CCP(=O)(O)OCC([R])C(=O)O</smiles>

$7838 \%$ for 4 steps

$$
\begin{aligned}
& \mathrm{R}^{1}=\mathrm{OH}, \mathrm{NHAc} ; \mathrm{R}^{2}=\mathrm{R}^{3}=\mathrm{H}, \mathrm{OH} ; \mathrm{R}^{4}=\mathrm{H}, \mathrm{CH}_{2} \mathrm{OH} \\
& \mathrm{R}=\left(\mathrm{CH}_{2}\right)_{11} \mathrm{CH}_{3}, \mathrm{CH}_{2}\left(\mathrm{CH}_{2} \mathrm{CHMeCH}_{2} \mathrm{CH}_{2}\right)_{2} \mathrm{CH}_{2} \mathrm{CHMe}_{2}
\end{aligned}
$$




\section{Synthesis of $\mathrm{Y}$-phosphonodepsipeptides}

$\gamma$-Phosphonodepsipeptides 79 have been prepared from $\mathrm{N}$-CbzL-glutamic acid (80) and diethyl 2-hydroxyglutarate (84). To prepare phosphorus analogues of $\gamma$-glutamyl peptide, the starting $N$-Cbz-L-glutamic acid (80) was first transformed to the corresponding dimethyl phosphonate 81. After aminolysis and chlorination the corresponding phosphonochloridate 83 was obtained. The latter was further reacted with diethyl 2-hydroxyglutarate (84), affording $\gamma$-phosphonodepsidipeptide $\mathbf{7 9}$ in only $6.7 \%$ yield, indicating that this strategy was not suitable for the synthesis of $\gamma$-phosphonodepsipeptides (Scheme 13) [28].

Folylpolyglutamate synthetase catalyzes an ATP-dependent ligation reaction. The reaction results in the synthesis of poly $(\gamma-$ glutamate) metabolites of folates and some antifolates. Three $\gamma$-phosphonodepsidipeptide derivatives $\mathbf{8 5}$ were designed as prototypes and mechanism-based folylpolyglutamate synthetase inhibitors. The synthesis started with dimethyl $\mathrm{N}$-phthaloyl-pro- tected $\gamma$-aminophosphonate $\mathbf{8 6}$ that was selectively hydrolyzed with thiophenol, affording the corresponding phosphonic monomethyl ester $\mathbf{8 7}$. The ester $\mathbf{8 7}$ was then coupled with dibenzyl (S)-2-hydroxypentanedioate (88) using BOP as the activating agent to generate the $\gamma$-phosphonodepsidipeptide $\mathbf{8 9}$. After hydrazinolysis, acylation with arenecarbonyl chlorides or arenecarboxylic acids, and further modification, the $\gamma$-phosphonodepsidipeptide derivatives $\mathbf{8 5}$ were obtained. The phosphonate moiety in these analogues represented an important new lead in the development of folylpolyglutamate synthetase inhibitors (Scheme 14) [29].

$\gamma$-Phosphonodepsipeptides were also designed and synthesized as potent inhibitors and active site probes of $\gamma$-glutamyl transpeptidase, which catalyzes the transfer of the $\gamma$-glutamyl group of glutathione and related $\gamma$-glutamyl amides to amino acids and peptides (transpeptidation) or to water (hydrolysis). For this purpose, $N$-Cbz-aminophosphonic acid $\mathbf{9 1}$ was first transformed to the corresponding dichloride 92, which under-

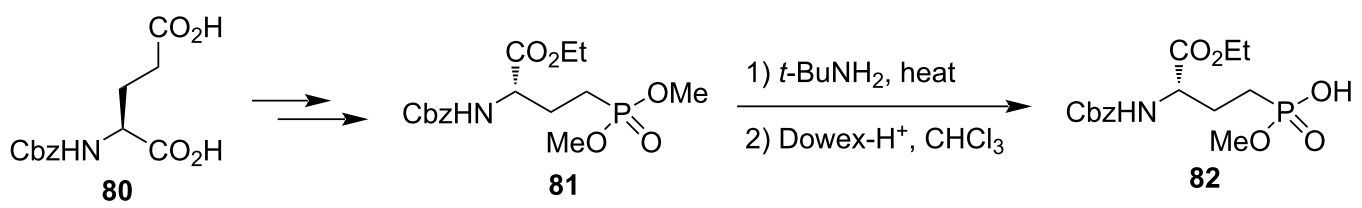

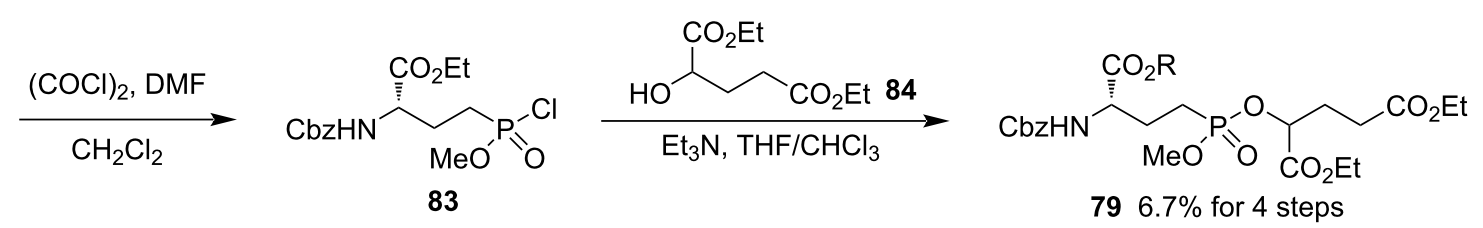

Scheme 13: Synthesis of $y$-phosphonodepsidipeptides.
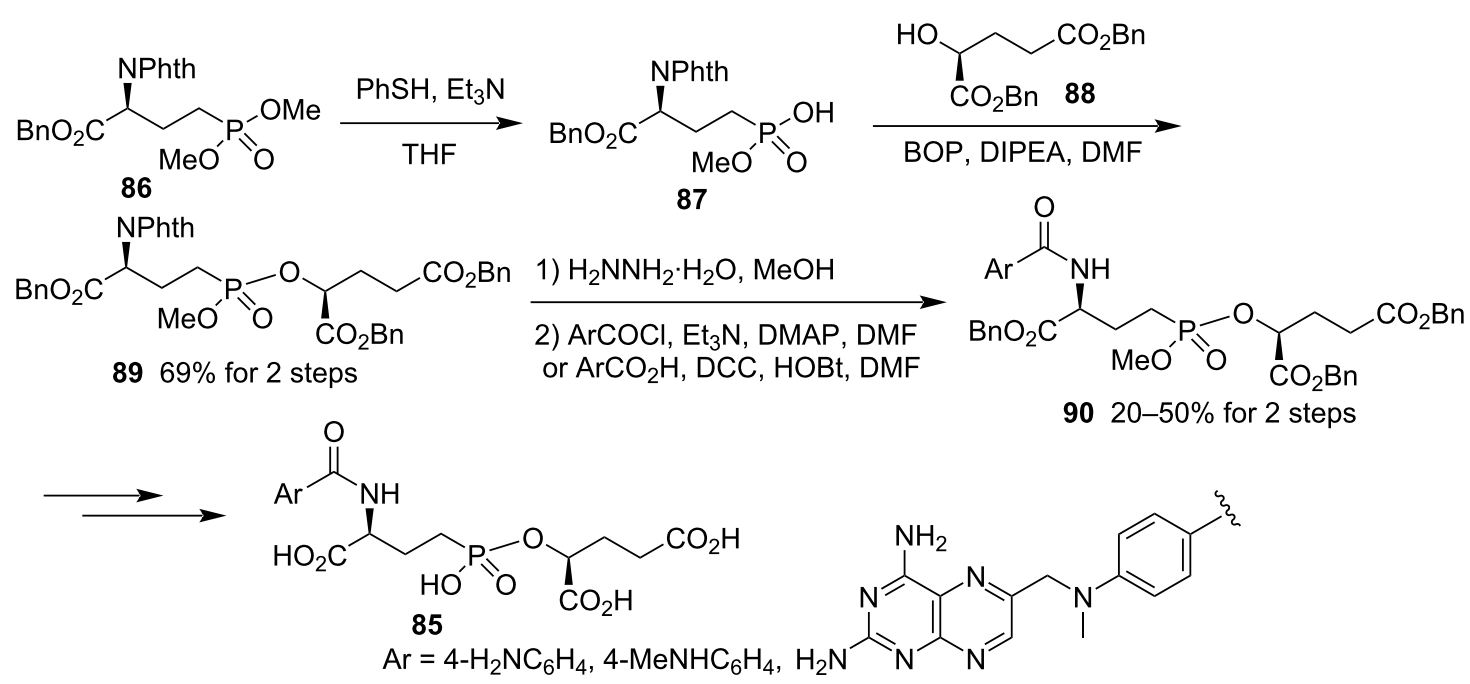
went a sequential alcoholysis with phenol and benzyl (4-hydroxybutanoyl)glycinate (93), respectively, to give the protected phosphonodepsitripeptide 94. After hydrogenolysis, the free $\gamma$-phosphonodepsitripeptide 95 was obtained (Scheme 15) [30].

Seven years later, various enantiopure 2-hydroxyalkanoic acids 96 were prepared from optically pure amino acids and converted to the benzyl or methyl [2-hydroxyalkanoyl]glycinates
97. Following the similar strategy, phosphonodepsitripeptides 99 and 102 were synthesized. The phosphonodepsidipeptide 104 was prepared through the sequential coupling of $N-\mathrm{Cbz}-\gamma-$ aminophosphonodichloride 92 with phenol and methyl $(S)$-2hydroxypentanoate (18). All synthetic phosphonodepsipeptides 99, 102, and 104 were considered as glutathione-analogue phosphonopeptides as mechanism-based inhibitors of $\gamma$-glutamyl transpeptidase for probing the cysteinyl-glycine binding site (Scheme 16) [31].

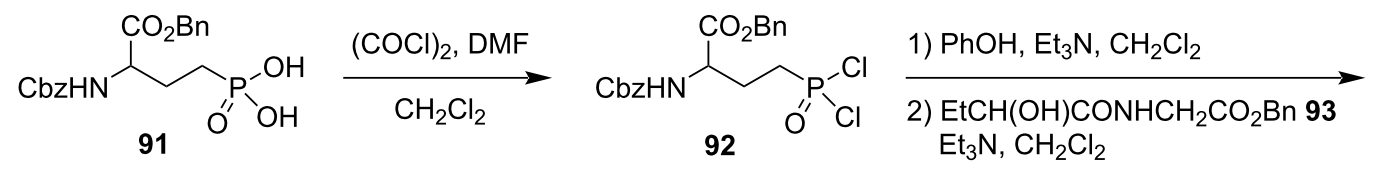<smiles>CCC(OP(=O)(CCC(NC(=O)OCc1ccccc1)C(=O)OCc1ccccc1)Oc1ccccc1)C(=O)NCC(=O)OCc1ccccc1</smiles>

$9415 \%$ for 3 steps<smiles>CCC(OP(=O)(O)P(=O)(O)CCC(N)C(=O)O)C(=O)NCC(=O)O</smiles>

$9518 \%$

Scheme 15: Synthesis of the $\gamma$-phosphonodepsitripeptide 95 as an inhibitor of $\gamma$-gutamyl transpeptidase.

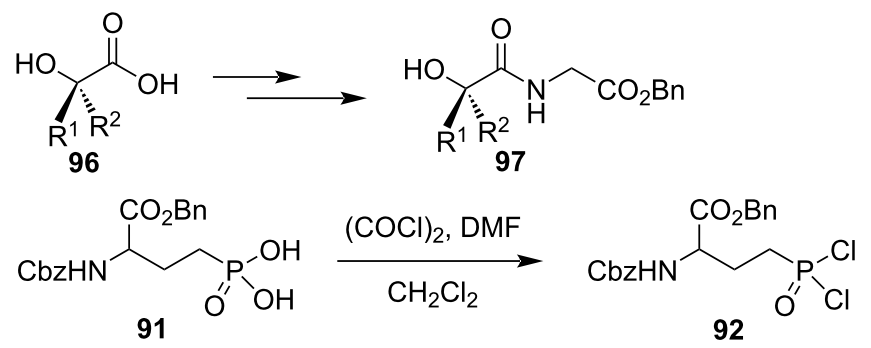

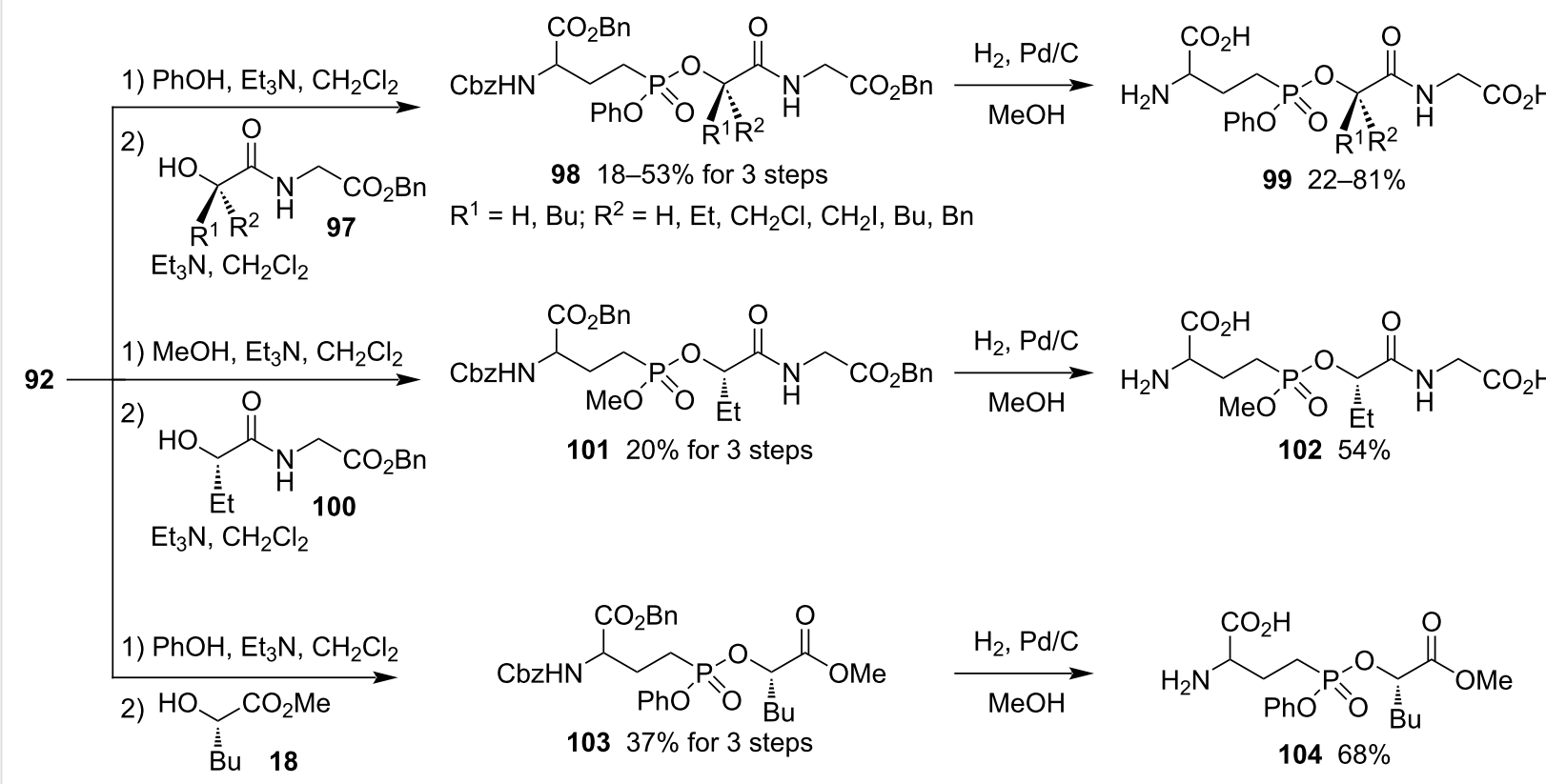

$\mathrm{Et}_{3} \mathrm{~N}, \mathrm{CH}_{2} \mathrm{Cl}_{2}$ 


\section{Synthesis of phosphonodepsipeptides via the condensation of phosphonic monoesters and hydroxy esters}

The condensation of $\mathrm{N}$-protected aminoalkylphosphonic monoesters and hydroxy esters is an alternative general strategy that has been widely used for the synthesis of phosphonodepsipeptides with various coupling reagents including the Mitsunobu reagent.

\section{Synthesis of $\alpha$-phosphonodepsipeptides}

$N, N$ '-Dicyclohexylcarbodiimide (DCC) was the first attempted coupling reagent in the synthesis of phosphonyl depsipeptides 108 from hydrogen 4-phenylbutylphosphinic acid (105) and 2-hydroxypropanoic acid derivatives 106 followed by oxidation. The corresponding phosphinyl depsipeptides 107 were generated and further oxidized into phosphonyl depsipeptides 108 (Scheme 17) [32].

The protected phosphonodepsidipeptides $\mathbf{1 1 1}$ were prepared without racemization from $N$-Cbz-protected $\alpha$-aminoalkylphosphonic monomethyl (12h) or benzyl esters 109 and hydroxy esters 110 by using (1H-benzotriazol-1-yloxy)tris(dimethylamino)phosphonium hexafluorophosphate (BOP) or ( $1 H$-benzotriazol-1-yloxy)tripyrrolidinophosphonium hexafluorophosphate (PyBOP) as activating agents as well (Scheme 18) [33]

The synthetic method was further investigated and compared with alternative coupling reagents. Various optically active phosphonodepsidipeptides 113-118 were synthesized. The reac- tion mechanism was further studied, revealing that the reaction proceeds through benzotriazolyl esters as was shown by the comparison with other coupling reagents, including DCC, DCC/ DMAP, DCC/1-hydroxybenzotriazole (HOBt), bromotris(dimethylamino)phosphonium hexafluorophosphate (BroP), or $O$-(1H-benzotriazol-1-yl)- $N, N, N^{\prime}, N^{\prime}$-tetramethyluronium hexafluorophosphate (HBTU) and by ${ }^{31} \mathrm{P}$ NMR analysis. The results indicated that the intermediates, benzotriazolyl phosphonates, were more reactive toward alcohols (hydroxy esters) than toward amines (amino esters), contrary to their carboxylic partners (Scheme 19) [34].

The coupling reagents $\mathrm{BroP}$ and $N, N, N^{\prime}, N^{\prime}$-bis(tetramethylene)chlorouronium tetrafluoroborate (TPyCIU) were applied as activating agents in the synthesis of phosphonodepsidipeptides 121 from $N$-Cbz-1-amino-2-phenylethylphosphonic acid (119) and hydroxy esters 120 in the presence of diisopropylethylamine (DIPEA) in $\mathrm{CH}_{2} \mathrm{Cl}_{2}$ (Scheme 20) [35].

Vancomycin resistance became a serious health care problem currently. The development of a catalytic monoclonal antibody to hydrolyze the depsidipeptide D-Ala-D-Lac was a new antibiotic strategy. In this regard, the phosphonodepsipeptide hapten 127 was designed to induce the antibody. First, $N$-Boc- $(S)-1$ aminoethylphosphinic acid (122) was coupled with benzyl alcohol in the presence of DCC as the coupling reagent, affording the benzyl $N$-Boc-1-aminoethylphosphinate 123. Oxidation with sodium periodate and neutralization with adamantan-1-amine (124), afforded the adamantan-1-ammoni-<smiles></smiles>

Scheme 17: Synthesis of phosphonyl depsipeptides 108 via DCC-mediated condensation and oxidation.

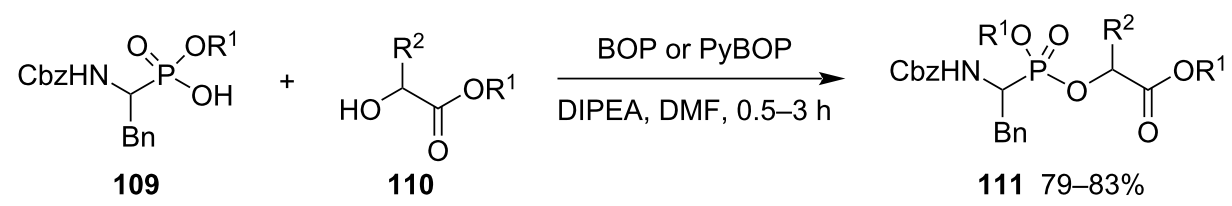

$\mathrm{R}^{1}=\mathrm{Me}, \mathrm{Bn} ; \mathrm{R}^{2}=\mathrm{H}, \mathrm{Me}, \mathrm{iPr}, \mathrm{s}-\mathrm{Bu}$ 
<smiles>O=C([O-])NC(Br)C(Br)NC(=O)P(=O)(O)OCc1ccccc1</smiles>

$\mathrm{R}=\mathrm{H}, \mathrm{Me}$<smiles>O=C(NC(Cc1ccccc1)P(=O)(O)OCc1ccccc1)c1ccccc1</smiles>

112<smiles>O=C(NC(Cc1ccccc1)P(=O)(O)OCc1ccccc1)c1ccccc1</smiles>

(S)-112<smiles>CC(C)[C@H](O)C(=O)OCc1ccccc1</smiles>

(R)-26d<smiles>CC(C)C(O)C(=O)OCc1ccccc1</smiles>

(S)-26d<smiles>O=C(O[Ga]OP(=O)(O)C(=O)N[C@H](Br)c1ccccc1)c1ccccc1</smiles>

(S)-112<smiles>CCC(C)C(O)C(=O)OCc1ccccc1</smiles>

(S)-26i<smiles>COP(=O)(O)C(NC(=O)OCc1ccccc1)C(C)C</smiles>

12d<smiles>COP(=O)(O)C(NC(=O)OCc1ccccc1)C(C)C</smiles>

12d<smiles>COC(=O)CO</smiles>

106<smiles>CCC(C)C(O)C(=O)OCc1ccccc1</smiles>

(S)-26i $\underset{\text { DIPEA, DMF, } 0.5-2 \mathrm{~h}}{\stackrel{\text { BOP or PyBOP }}{\longrightarrow}}$<smiles>[R]C(OP(=O)(OCc1ccccc1)C(Cc1ccccc1)NC(=O)c1ccccc1)C(=O)OCc1ccccc1</smiles>

$11382-85 \%$

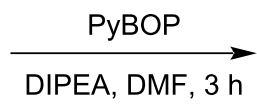<smiles>CC(C)[C@H](OP(=O)(OCc1ccccc1)C(Cc1ccccc1)C(=O)NC(=O)OCc1ccccc1)C(=O)Cc1ccccc1</smiles>

$11481 \%$<smiles>CC(C)C(OP(=O)(OCc1ccccc1)C(Cc1ccccc1)C(=O)NC(C)(C)C)C(=O)OCc1ccccc1</smiles>

115 85\%<smiles>CCC(C)C(OP(=O)(OCc1ccccc1)C(Cc1ccccc1)NC(=O)OCc1ccccc1)C(=O)Cc1ccccc1</smiles>

$11681 \%$<smiles>COC(=O)COP(=O)(OC)C(NC(=O)OC)C(C)C</smiles>

$11775 \%$<smiles>CCC(C)[C@H](OP(=O)(OC)C(NC(=O)c1ccccc1)C(C)C)C(=O)Cc1ccccc1</smiles>

$11865 \%$

Scheme 19: Synthesis of optically active phosphonodepsipeptides with BOP and PyBOP as coupling reagents.

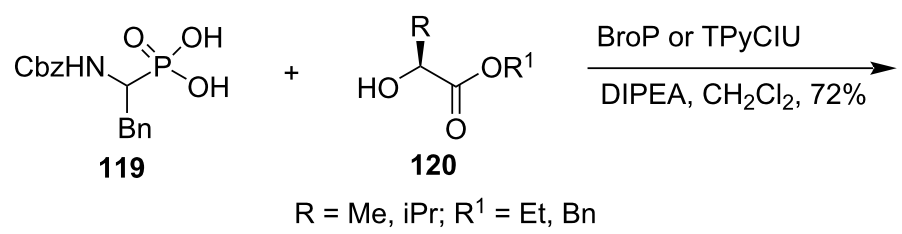<smiles>[R]OC(=O)C([R])OP(=O)(O)C(Cc1ccccc1)N[C+]#[Co]</smiles>

$12170-100 \%$

Scheme 20: Synthesis of phosphonodepsipeptides with BroP and TPyCIU as coupling reagents.

um benzyl phosphonate 125. After treated with hydrochloride and coupled with benzyl D-lactate $((R)-\mathbf{2 6 b})$ with BOP as activating reagent, the ammonium compound 125 was transformed to the protected phosphonodepsidipeptide 126 (Scheme 21) [12], that was further converted to the designed hapten $\mathbf{1 2 7 .}$
The new muramyl dipeptide (MDP) phosphorus analogue 131 related to LK 423 as potential immunomodulator was prepared by the coupling of methyl 1-(N-benzyloxycarbonyl)aminoethylphosphonate (12b) and $(R)$-2-hydroxyglutaric acid dimethyl ester (128) with BOP as coupling reagent, followed by 


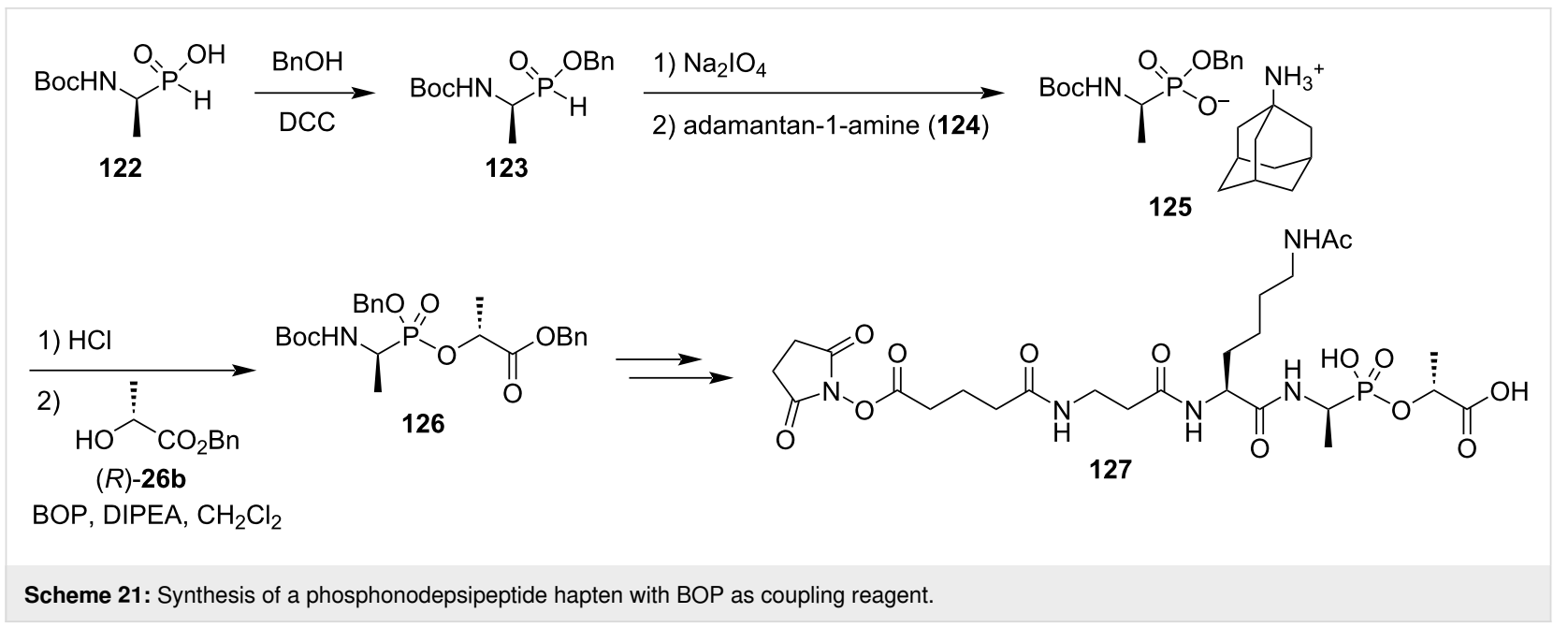

hydrogenolysis and coupling with 2-(2-phthalimidoethoxy)acetic acid (130). The amide bond between L-Ala and D-Glu was replaced by a phosphonate isostere, giving the phosphonodepsipeptide 131 (Scheme 22) [36].

The synthesis of the norleucine-derived phosphonodepsipeptides $\mathbf{1 3 5}$ and $\mathbf{1 3 8}$ was realized by a BOP-activated coupling of $\mathrm{N}$-Cbz-1-aminopentylphosphonic monobenzyl ester (132), a phosphorus analogue of norleucine, with derivatives $\mathbf{1 3 3}$ and 136 of $(S)$-lactic or glycolic acids followed by hydrogenolysis (Scheme 23) [37].

Following a similar strategy, phosphonodepsidipeptides 141 and phosphonodepsitripeptides $\mathbf{1 4 4}$ were synthesized as norleucine-derived phosphonopeptides (Scheme 24) [38].

The protected phosphonodepsipeptide 145 was applied in a solid-phase phosphonodepsipeptide synthesis. After hydro- genolysis and reaction with Fmoc-OSu, the $N$-protected phosphonodepsipeptide 145 was transformed to the $N$-Fmoc-protected phosphonodepsidipeptide $\mathbf{1 4 7}$, which was then coupled with the resin-loaded Cys(Trt)-NH-resin 148. The resin-loaded tripeptide 149 was deprotected with piperidine, coupled with Fmoc- $\mathrm{Tyr}(\mathrm{O} t-\mathrm{Bu})$ 150, deprotected again with piperidine, and cleaved with TFA and trapping agents. The free phosphonodepsipeptide $\mathbf{1 5 1}$ was obtained in $45 \%$ yield after HPLC purification (Scheme 25) [38].

A general and high yielding synthesis of phosphonodepsidipeptides 152 was realized via a Mitsunobu reaction of the $N$-Cbz-1aminophosphonic monomethyl esters $\mathbf{1 2 b}, \mathbf{d}$ and hydroxy esters 106 followed by the selective demethylation with TMSBr in a one-pot reaction. The method provides a mild route to prepare phosphonodepsipeptides. The yields were insensitive to the steric encumbrance of both reactants being coupled (Scheme 26) [39].

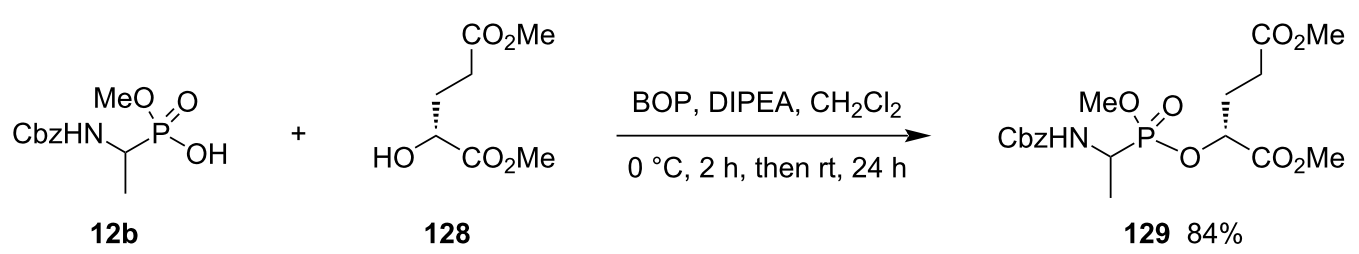

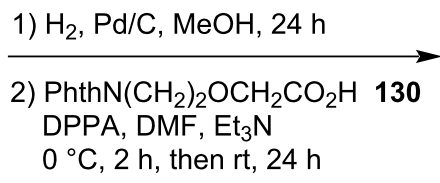

1) $\mathrm{H}_{2}, \mathrm{Pd} / \mathrm{C}, \mathrm{MeOH}, 24 \mathrm{~h}$

DPPA, DMF, $\mathrm{Et}_{3} \mathrm{~N}$<smiles>CO[P+]([O-])(OC(C)C(=O)NC(=O)COCCNc1ccccc1)OC(CCC(C)=O)C(C)=O</smiles>

$13168 \%$ 


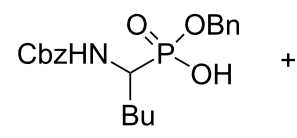

132<smiles>[R]C(=O)C([R])O</smiles>

133 $\underset{\text { rt, overnight }}{\stackrel{\text { BOP, TEA, DMF }}{\longrightarrow}}$

$\mathrm{R}=\mathrm{H}, \mathrm{Me} ; \mathrm{R}^{1}=\mathrm{OBn}, \mathrm{OMe}, \mathrm{NH}_{2}$

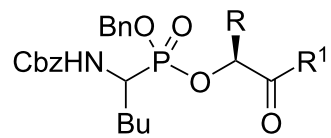

$13470-88 \%$

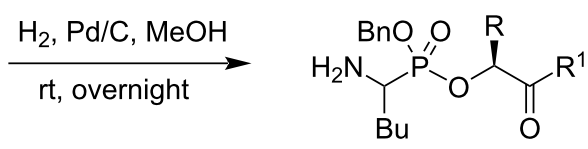

$$
\begin{aligned}
& 135 \text { 56-78\% }
\end{aligned}
$$

$\mathrm{R}=\mathrm{H}, \mathrm{Me} ; \mathrm{R}^{1}=\mathrm{OH}, \mathrm{OMe}, \mathrm{NH}_{2}$

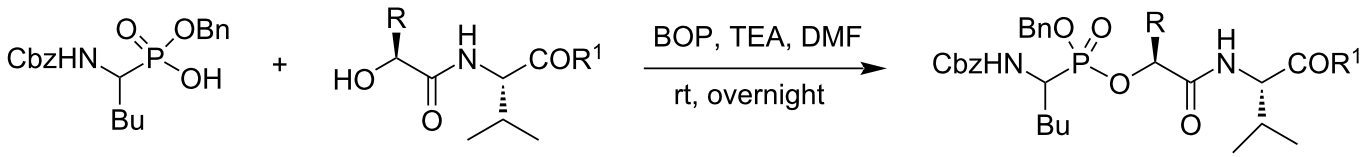

132

136

$\mathrm{R}=\mathrm{H}, \mathrm{Me} ; \mathrm{R}^{1}=\mathrm{OBn}, \mathrm{OMe}, \mathrm{NH}_{2}$

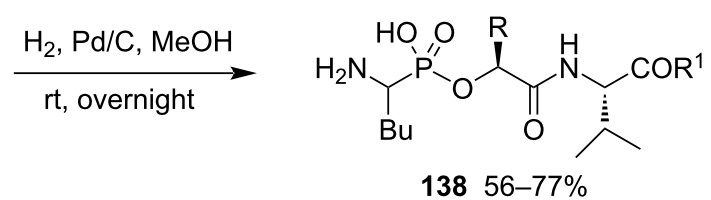

$\mathrm{R}=\mathrm{H}, \mathrm{Me} ; \mathrm{R}^{1}=\mathrm{OH}, \mathrm{OMe}, \mathrm{NH}_{2}$

Scheme 23: Synthesis of norleucine-derived phosphonodepsipeptides 135 and 138.
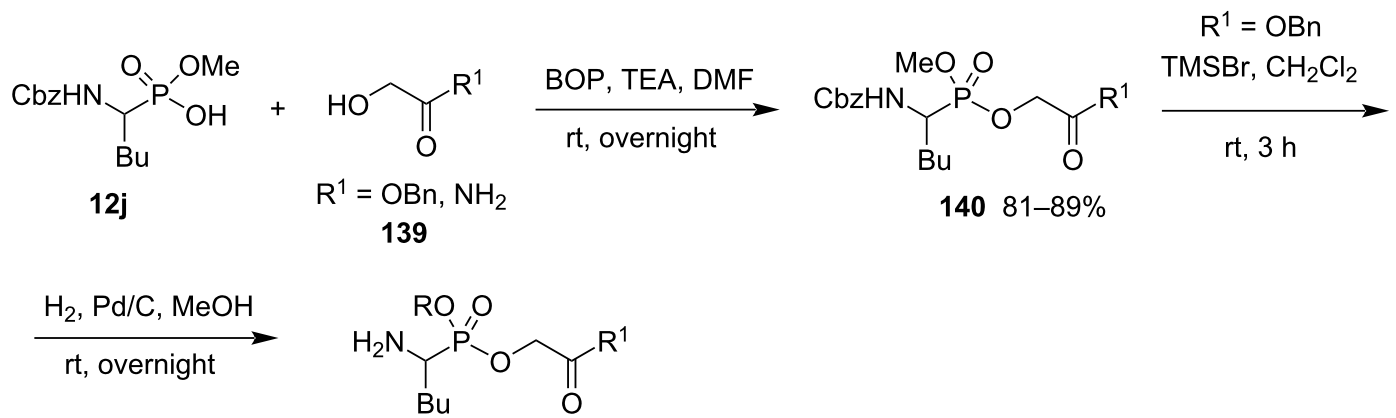

141a $R^{1}=\mathrm{OH}, \mathrm{R}=\mathrm{H} 3 \%$ for 3 steps

141b $\mathrm{R}^{1}=\mathrm{NH}_{2}, \mathrm{R}=\mathrm{Me}, 59 \%$<smiles>COP(=O)(O)C(CC(C)(C)C)NC(=O)c1ccccc1</smiles>

$12 \mathrm{j}$<smiles>CC(C)[C@H](NC(=O)CO)C(=O)OCc1ccccc1</smiles>

142

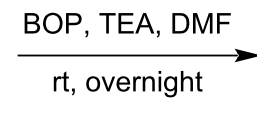

$\underset{\text { rt, overnight }}{\stackrel{\mathrm{H}_{2}, \mathrm{Pd} / \mathrm{C}, \mathrm{MeOH}}{\longrightarrow}}$<smiles>COP(=O)(OCC(=O)N[C@H](C(=O)O)C(C)C)C(C)Br</smiles> 


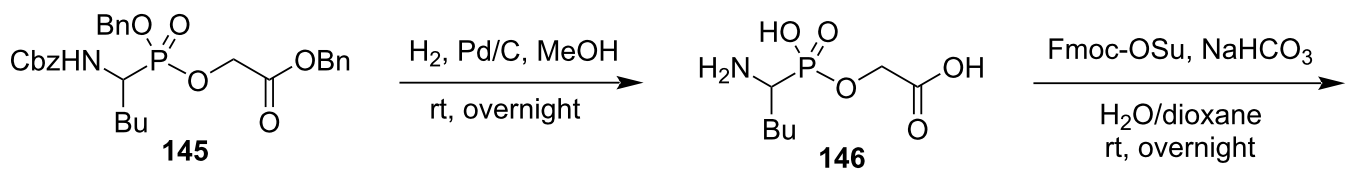

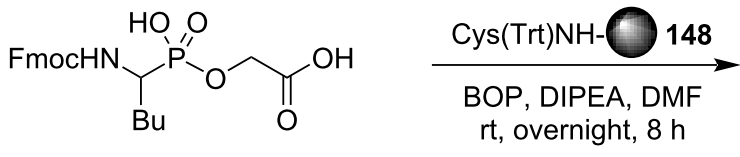

$14722 \%$ for 2 steps<smiles>O=CC(Br)P(=O)(O)OCC(=O)N[C@@H](C[SH+])C(=O)Nc1ccccc1</smiles>

149

1) piperidine, $D M F$

2) Fmoc-Tyr(Ot-Bu) 150, BOP DiPEA, DMF, rt, $1 \mathrm{~h}$

3) piperidine, DMF

4) TFA cleavage<smiles>CC(C)(C)CC(NC(=O)[C@H](N)Cc1ccc(O)cc1)P(=O)(O)OCC(=O)N[C@@H](CS)C(N)=O</smiles>

Scheme 25: Solid-phase synthesis of phosphonodepsipeptides.

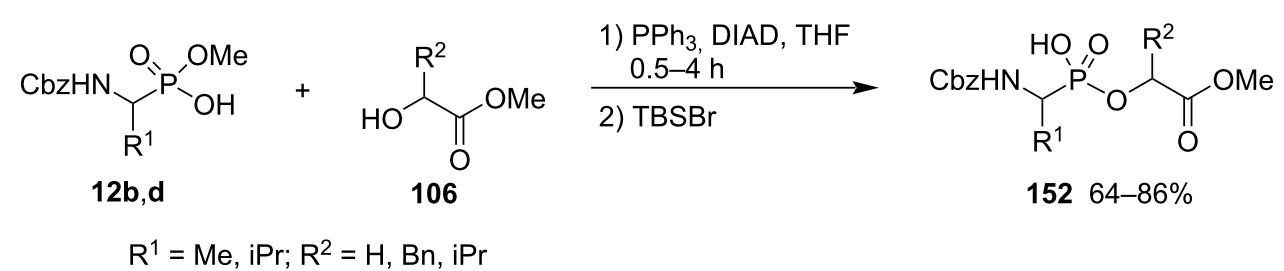

Scheme 26: Synthesis of phosphonodepsidipeptides via the Mitsunobu reaction.

\section{Synthesis of $\mathrm{Y}$-phosphonodepsipeptides}

To prepare phosphorus analogues of $\gamma$-glutamyl peptide, $\mathrm{N}$-CbzL-glutamic acid (80) was initially converted to the corresponding dimethyl phosphonate $\mathbf{8 1}$ and further to the methyl phos- phonic monoester $\mathbf{8 2}$. The ester $\mathbf{8 2}$ was then coupled with diethyl 2-hydroxyglutarate $(\mathbf{8 4})$ in a Mitsunobu reaction to generate the $\gamma$-phosphonodepsipeptide 79 in a high yield of $66 \%$ (Scheme 27) [28].

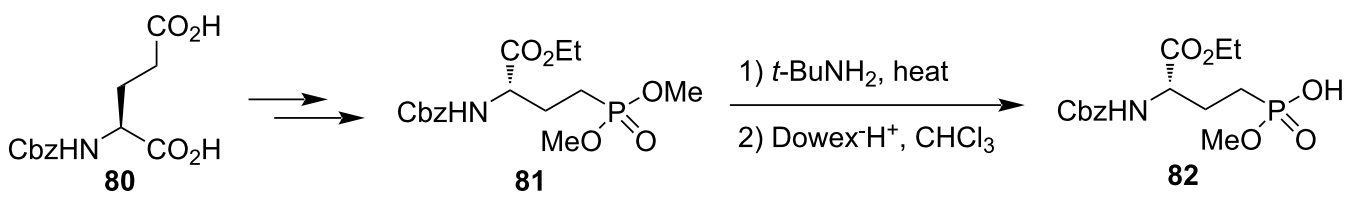<smiles>CCOC(=O)CCC(O)C(O)C(=O)OCC</smiles>

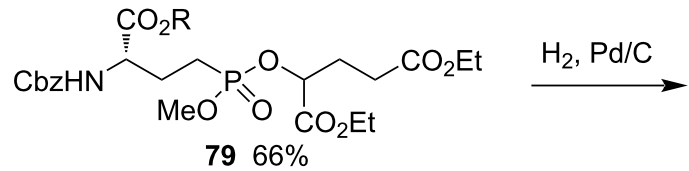<smiles>[R]OC(=O)CCCC(OCC)OP(=O)(OC)OCCC(=O)OCC</smiles> 


\section{Synthesis of phosphonodepsipeptides via the multicomponent condensation of amides, aldehydes, and phosphites followed by alcoholysis with hydroxy esters}

Previously, the Mannich-type reaction of benzyl carbamate, aldehydes, and trialkyl phosphites in acetyl chloride gave rise to $N$-Cbz-1-aminoalkylphosphonates [40]. When the reactions were conducted in benzene followed by an aminolysis or alcoholysis, phosphonamidates [41], phosphonopeptide [42], and mixed esters $[43,44]$ were obtained directly. The multicomponent condensation reaction was applied as a direct synthetic method for phosphonodepsipeptides via the formation of 1-aminoalkylphosphonic acids and simultaneous construction of the phosphonate bond. A series of phosphonodepsipeptides 158 was prepared in good yields in a one-pot reaction directly from the simple and commercially available chemicals, benzyl carbamate (154), aldehydes 155, and methyl dichlorophosphite (156), followed by the alcoholysis with the hydroxy esters 157 . The current strategy is a highly efficient and convergent synthesis of phosphonodepsipeptides that does not require the preparation of 1-aminoalkylphosphonic acid or 1-aminoalkylphosphonous acid derivatives first as starting materials (Scheme 28) [42].
Similarly, phosphinopeptides [45,46], phosphinodepsipeptides [47], and hybrid sulfonophosphinopeptides [48,49] were prepared from amino amides and 2-aminoalkanesulfonamides by using this strategy.

Also side-chain functionalized phosphonodepsipeptides $\mathbf{1 6 0}$ were prepared in satisfactory yields directly through the one-pot reactions of benzyl carbamate (154), aldehydes $\mathbf{1 5 5}$, and diethyl $(R, R)$-2-chloro-1,3,2-dioxaphospholane-4,5-dicarboxylate (159), which was synthesized from diethyl L-tartrate and phosphorus trichloride. A pair of diastereomeric products $\mathbf{1 6 0}$ was obtained in diasteromeric ratios of $1.7: 1.0$ to $2.5: 1.0$. The configuration of the major diastereomeric product was determined by hydrolysis of the product 160a and comparison of the obtained acid $(R)$-161a with the corresponding reported authentic sample (Scheme 29) [50].

A straightforward method for the synthesis of phosphonodepsipeptides 163 was developed via the multicomponent condensation reaction of the simple starting materials, benzyl carbamate (154), aldehydes 155, and 1-ethoxycarbonylalkyl phosphorodichloridites $\mathbf{1 6 2}$, which were prepared from ethyl 2-hydroxyalkanoates 157 and phosphorus trichloride. Compared with the

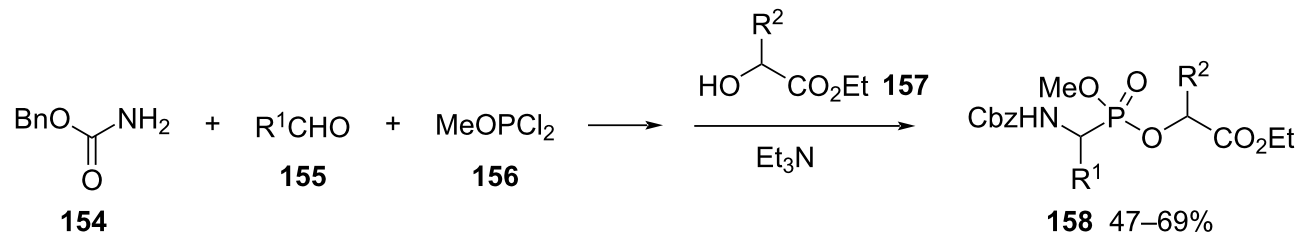

$\mathrm{R}^{1}=\mathrm{Ph}, 4-\mathrm{MeC}_{6} \mathrm{H}_{4}, 4-\mathrm{MeOC}_{6} \mathrm{H}_{4}, 4-\mathrm{ClC}_{6} \mathrm{H}_{4} ; \mathrm{R}^{2}=\mathrm{Me}, \mathrm{CH}_{2} \mathrm{CH}_{2} \mathrm{CO}_{2} \mathrm{Et}$

Scheme 28: Synthesis of phosphonodepsipeptides via a multicomponent condensation reaction.
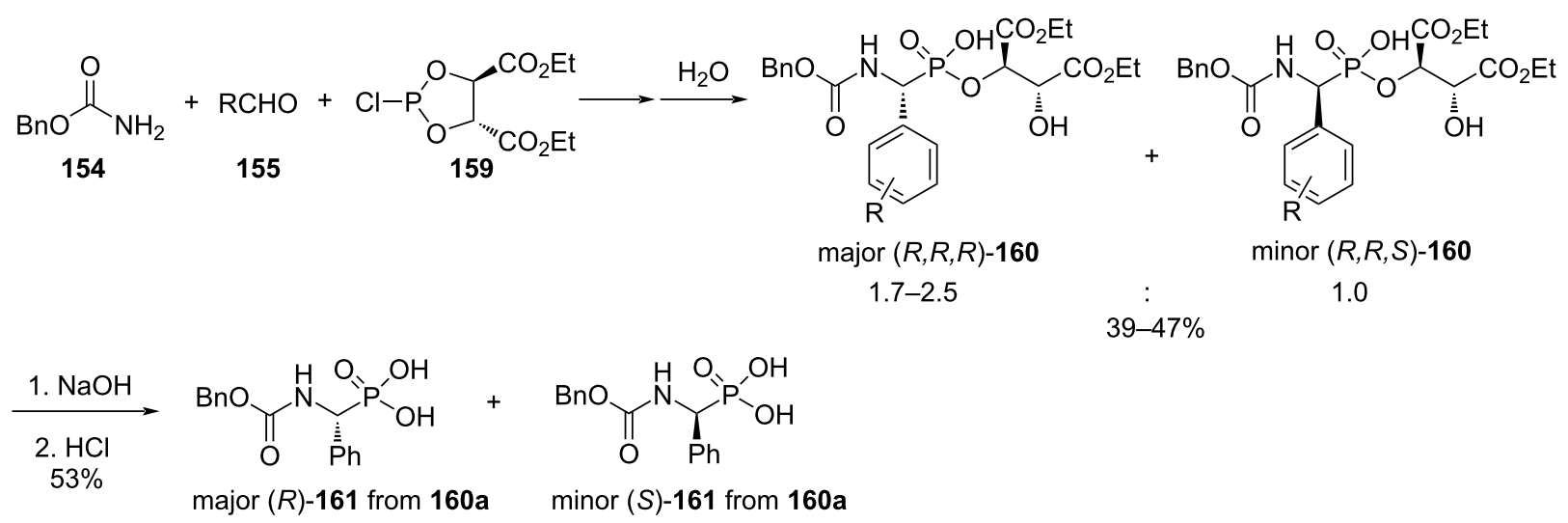

a: $\mathrm{R}=\mathrm{Ph} ; \mathbf{b}: \mathrm{R}=4-\mathrm{MeC}_{6} \mathrm{H}_{4} ; \mathbf{c}: \mathrm{R}=4-\mathrm{ClC}_{6} \mathrm{H}_{4} ; \mathbf{d}: \mathrm{R}=4-\mathrm{BrC}_{6} \mathrm{H}_{4} ; \mathbf{e}: \mathrm{R}=4-\mathrm{NO}_{2} \mathrm{C}_{6} \mathrm{H}_{4} ; \mathbf{f}: \mathrm{R}=3-\mathrm{ClC}_{6} \mathrm{H}_{4}$ 
previous methods, the current strategy provides a more efficient, convenient, convergent, and practical synthetic route to phosphonodepsipeptides 163 under mild reaction conditions with good yields. Good diastereoselectivities were observed with diastereomeric ratios of 84:12 to 88:12 (Scheme 30) [51]. However, when using substrates with arylmethyl groups, the phosphorodichloridites favored an elimination reaction generating the corresponding ethyl cinnamate derivatives during their preparation.

To prepare optically active phosphonodepsipeptides, ethyl $(R)$ 2-((dichlorophosphanyl)oxy)-2-phenylacetate $((R)-\mathbf{1 6 2 c})$ was first prepared through the reaction of ethyl $(R)$-2-hydroxy-2phenylacetate and phosphorus trichloride and further reacted with benzyl carbamate (154) and benzaldehyde (155a), affording a pair of optically active phosphonodepsipeptides 164 and 165 in an 86\% yield and 85:15 diastereomeric ratio (Scheme 31) [51].

Following a similar strategy, the three component condensation of diethyl phosphoramidate (166), aromatic aldehydes $\mathbf{1 6 7}$, and diisopropyl $(4 R, 5 R)$-2-chloro-1,3,2-dioxaphospholane-4,5dicarboxylate (168) gave the corresponding phosphonodepsipeptides 169 in $65-86 \%$ yields under mild conditions. Although the diisopropyl ester was applied instead of diethyl L-tartrate, a low diastereoselectivity (ratios varied from 55:45 to
67:33) was observed as well. Acetophenone (170) produced the desired product $\mathbf{1 7 1}$ in $62 \%$ yield in the reaction. However, aliphatic aldehydes did not work (Scheme 32) [52].

\section{Synthesis of phosphonodepsipeptides via the alkylation of phosphonic monoesters with 1-(alkoxycarbonyl)alkyl halides or sulfonates}

The alkylation of $N$-protected 1 -aminoalkylphosphonic monoesters with 1-(alkoxycarbonyl)alkyl halides or sulfonates is also a general method for the synthesis of phosphonodepsipeptides. However, the strategy has not been utilized widely.

\section{Synthesis of $\alpha$-phosphonodepsipeptides}

Skwarczynski and Kafarski synthesized various alkyl 1-aminoalkylphosphonates via the nucleophilic esterification of potassium 1-( $N$-benzyloxycarbonylamino)alkylphosphonates 172 with alkyl halides in the presence of 18-crown-6. They also prepared a phosphonodepsidipeptide $\mathbf{1 7 4}$ with ethyl chloroacetate (173) as an electrophile (Scheme 33) [53].

The macrocyclic peptidyl phosphonodepsipeptide 180 was designed on the basis of the acyclic conformational analog bound to the aspartic protease penicillopepsin. Dimethyl $\mathrm{N}$-Cbz-1amino-2-(naphthalen-2-yl)ethylphosphonate 176 was first prepared from 7-bromo-3,4-dihydronaphthalen-1(2H)-one (175) and further transformed to the macrocyclic peptidyl phosphonic<smiles>[R]C(O)C(=O)OCC</smiles>

157<smiles>[R]C(O[GaH])C(=O)OCC</smiles>

162

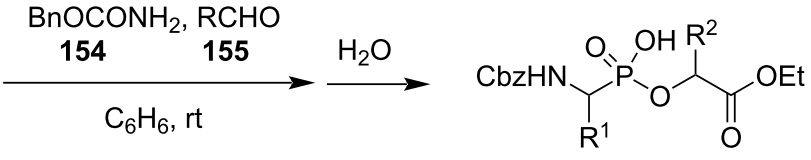

$16372-89 \%$, dr 84:16-88:12

$\mathrm{R}^{1}=\mathrm{Ph}, 4-\mathrm{ClC}_{6} \mathrm{H}_{4}, 4-\mathrm{BrC}_{6} \mathrm{H}_{4}, 4-\mathrm{MeOC}_{6} \mathrm{H}_{4} ; \mathrm{R}^{2}=\mathrm{H}, \mathrm{Me}, \mathrm{Ph}$

Scheme 30: High yielding synthesis of phosphonodepsipeptides via a multicomponent condensation.

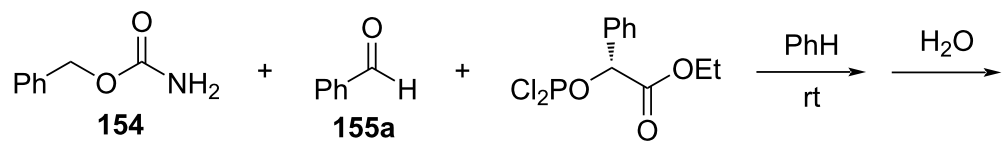

$(R)-162 c$<smiles>CCOC(=O)C(OP(=O)(O)C(NC(=O)OCc1ccccc1)c1ccccc1)P(C)(C)(C)(C)(F)F</smiles>

85<smiles>CCOC(=O)C(OP(=O)(O)C(NC(=O)OCc1ccccc1)c1ccccc1)c1ccccc1</smiles>

165

15 

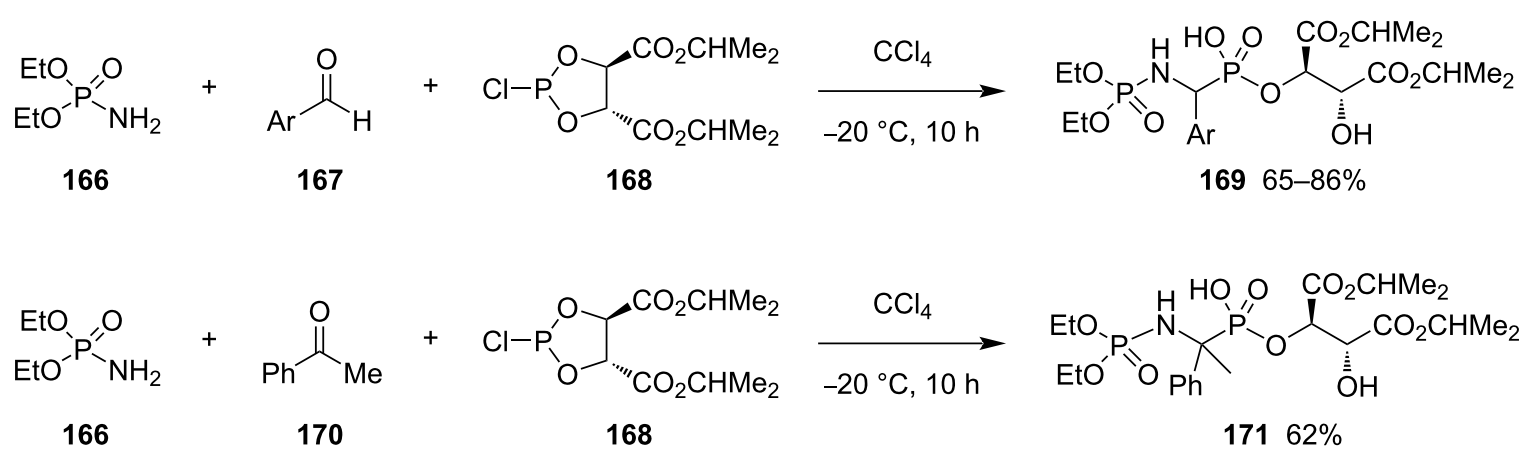

Scheme 32: Synthesis of $N$-phosphoryl phosphonodepsipeptides.

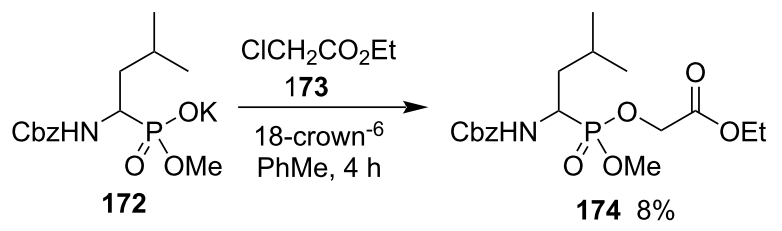

Scheme 33: Synthesis of phosphonodepsipeptides via the alkylation of phosphonic monoesters.

monomethyl ester 177. The latter compound was alkylated with methyl 3-phenyl-2-trifluoromethanesulfonyloxypropanoate (178) to produce the macrocyclic peptidyl phosphonodepsipeptide 179, which was selectively hydrolyzed with TMSBr and treated with Dowex- $\mathrm{Na}^{+}$to afford the macrocyclic peptidyl phosphonodepsipeptide sodium salt 180. By using a similar method, two acyclic analogues 183 and $\mathbf{1 8 6}$ were synthesized as well. The macrocyclic phosphonodepsipeptide $\mathbf{1 8 0}$ and the two acyclic analogues 183 and 186 were evaluated for their potential as inhibitors. The NMR analysis results indicated that the conformation of the macrocyclic phosphonodepsipeptide backbone closely approximated that of the lead inhibitor and showed the low-energy conformation accommodated in the active site of penicillopepsin without significant distortion (Scheme 34) [54].

\section{Synthesis of $y$-phosphonodepsipeptides}

The acyloxyalkyl esters 194 are derivatives of the new antimalarial drug fosmidomycin and inhibited the 1-deoxy-D-xylulose 5-phosphate reductoisomerase. The phosphonodepsipeptides 194 were synthesized as prodrugs with an increased activity after oral administration due to a chemical modification of the phosphonate moiety. For the synthesis, diethyl 3,3diethoxypropylphosphonate (187) was hydrolyzed to 3-oxopropylphosphonate $\mathbf{1 8 8}$, which underwent a reductive amination with benzyloxyamine to give diethyl 3-benzyloxyaminopropylphosphonate (189). After the sequential treat- ment with acetyl chloride and TMSBr, alkylation with methyl or tert-butyl chloroacetate 192, and hydrogenolysis, the target phosphonodepsipeptides 194 were obtained (Scheme 35) $[8,9,13]$.

\section{Synthesis of phosphonodepsipeptides via phosphinylation of hydroxy esters with phosphonochloridites followed by oxidation}

Hammer's group developed a new route to prepare phosphonodepsithioxopeptides 198 via the reaction of $N$-protected aminoalkylphosphonochloridites 196 with the hydroxy ester $(S)$-106b followed by sulfur oxidation. They first transformed the $N$-Boc-protected 1-aminoalkylphosphinate 195 to the corresponding phosphonochloridite 196 with dichlorotriphenylphosphorane. The phosphonochloridite $\mathbf{1 9 6}$ was then further reacted with methyl $(S)$-lactate $((S)$-106b) followed by sulfurization with sulfur, affording the phosphonodepsithioxopeptide 198 in a one-pot activation-coupling-oxidation procedure (Scheme 36 ) [55]. Although it was mentioned that the phosphonochloridites were a more active species than the corresponding phosphonochloridates in the esterification, this synthetic strategy had not been applied by others. There is only one example reported till now possibly due to the inconvenient preparation of the phosphonochloridites.

\section{Synthesis of phosphonodepsipeptides via the addition of tetraoxyspirophosphoranes to imines}

The addition reaction of the $\mathrm{P}-\mathrm{H}$ bond of tetraoxyspirophosphoranes 199 to long-chain imines 200 of benzaldehyde, acetaldehyde, and dodecanal at room temperature generated the corresponding ( $\alpha$-aminoalkyl)spirophosphoranes 201 via the Pudovik reaction. The one-pot selective hydrolysis of the $\mathrm{P}-\mathrm{C}$ bond of the spirophosphoranes $\mathbf{2 0 1}$ readily proceeded at room temperature in the presence of moist solvents to give the corresponding phosphonodepsipeptides $\mathbf{2 0 2}$ in high yields (Scheme 37) [56]. 
<smiles>O=C1CCCc2ccc(Br)cc21</smiles>

175<smiles>COC(=O)NC(Cc1ccc2cccc(CC(C)=O)c2c1)P(=O)(OC)OC</smiles>

176
1) $\mathrm{Me}_{4} \mathrm{NOH}, \mathrm{MeOH}$

2)<smiles>COC(=O)C(Br)Br</smiles>
$\mathrm{MeCN}, 78 \%$<smiles>COP(=O)(O)CNC(=O)C(NC(=O)Cc1cccc2ccccc12)C(C)C</smiles>

181

\section{1) $\mathrm{TMSBr}, \mathrm{CH}_{2} \mathrm{Cl}_{2}$}

2) Dowex- $\mathrm{Na}^{+}$
1) $\mathrm{Me}_{4} \mathrm{NOH}, \mathrm{MeOH}$

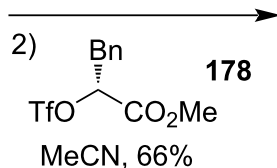

$\mathrm{MeCN}, 66 \%$<smiles>CC(=O)C(Cc1ccccc1)OP(=O)(O)CNC(=O)C(NC(=O)Cc1cccc2ccccc12)C(C)C</smiles>

$18376 \%$
1) LiSPr, HMPA

2) $\mathrm{Me}_{4} \mathrm{NOH}, \mathrm{MeOH}$

3)<smiles>CC1CCCC1</smiles>

2) Dowex- $\mathrm{Na}^{+}$<smiles>CO[C@@H](Cc1ccc2cccc(CC(=O)NC(C(=O)NC(=O)C(C)C)C(C)C)c2c1)P(=O)(O)OC</smiles>

177<smiles>CC(=O)OC(Cc1ccccc1)P(=O)(O)OC(Cc1ccc2cccc(CC(=O)NC(C(=O)O)C(C)C)c2c1)C(=O)O</smiles><smiles>COC(=O)C(Cc1ccccc1)OP(=O)(CNC(=O)C(NC(=O)Cc1cccc2ccccc12)C(C)C)OC</smiles>

182<smiles>COP(=O)(O)[C@H](Cc1ccc2ccccc2c1)NC(=O)C(NC(=O)O)C(C)C</smiles>

184

1) $\mathrm{TMSBr}, \mathrm{CH}_{2} \mathrm{Cl}_{2}$

2) Dowex- $\mathrm{Na}^{+}$

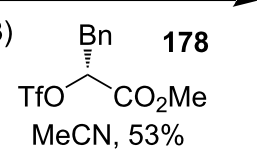<smiles>COC(=O)C(Cc1ccccc1)OP(=O)(O)[C@H](Cc1ccc2ccccc2c1)NC(=O)C(NC(=O)O)C(C)C</smiles><smiles></smiles>

Scheme 34: Synthesis of phosphonodepsipeptides as inhibitors of aspartic protease penicillopepsin.

An asymmetric synthesis of this class of phosphonodepsipeptides was realized with enantiopure $(S)$ - $\alpha$-hydroxyisovaleric acid-derived spirophosphoranes as the phosphorus reagents
[57]. By using a similar strategy, linker-linked bisphosphonodepsidipeptides were synthesized [10]. The current method is also an interesting synthetic strategy of phosphonodepsipep- 

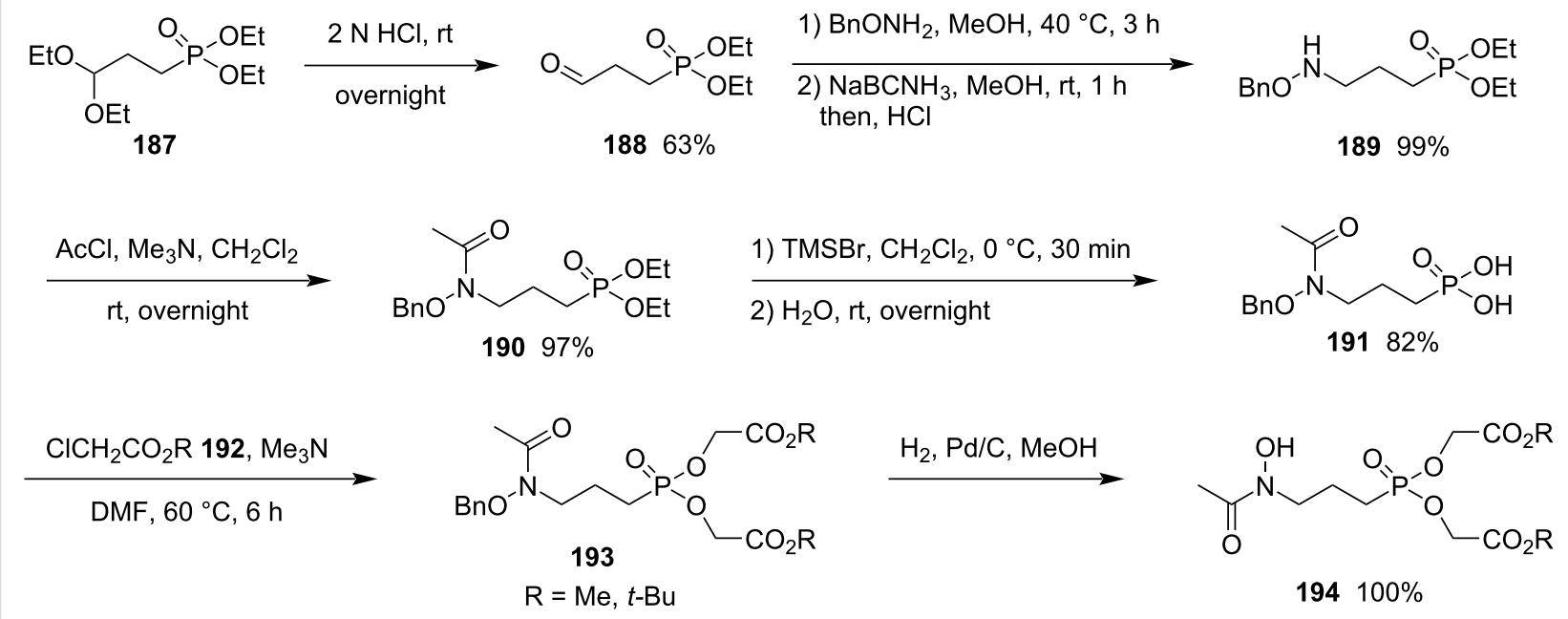

Scheme 35: Synthesis of phosphonodepsipeptides as prodrugs.

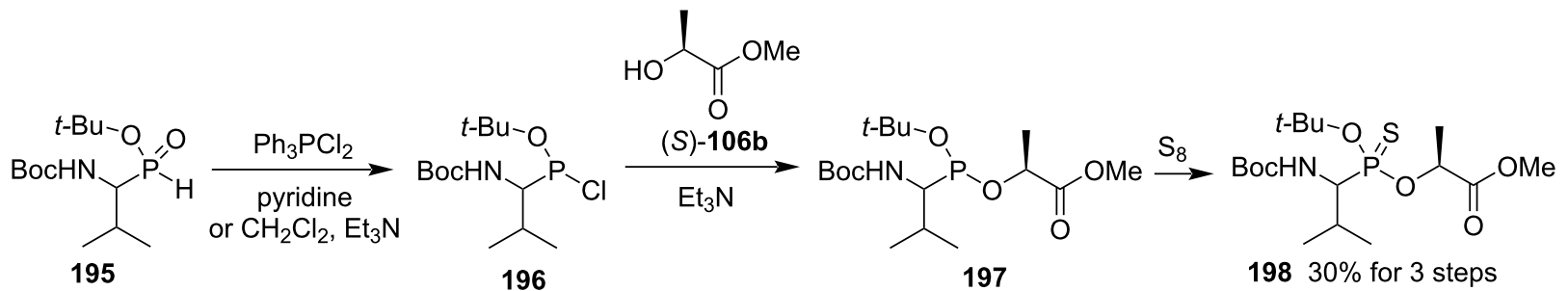

Scheme 36: Synthesis of phosphonodepsithioxopeptides 198.

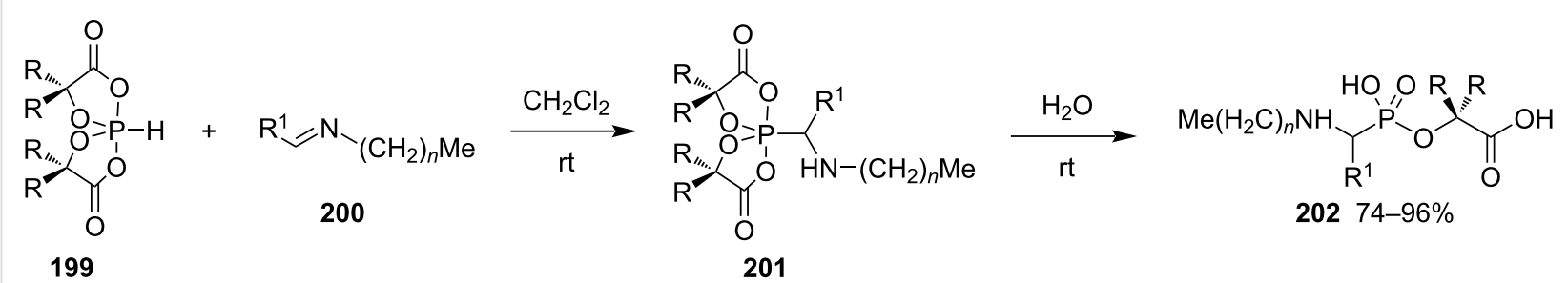

$\mathrm{R}=\mathrm{Me} ; n=9,11,13,15,17,\left(\mathrm{CH}_{2}\right)_{n} \mathrm{Me}=\left(\mathrm{CH}_{2}\right)_{8} \mathrm{CH}=\mathrm{CH}\left(\mathrm{CH}_{2}\right)_{7} \mathrm{Me}, \mathrm{R}^{1}=\mathrm{Ph}$

$\mathrm{R}=\mathrm{Ph}, n=17, \mathrm{R}^{1}=\mathrm{Me},\left(\mathrm{CH}_{2}\right)_{10} \mathrm{Me}$

Scheme 37: Synthesis of phosphonodepsipeptides.

tides. It can realize an asymmetric synthesis of phosphonodepsipeptides.

\section{Synthesis of phosphonodepsipeptides with} C-hydroxyalkylphosphonic acids

Phosphonodepsipeptides with C-1-hydroxyalkylphosphonic acids can be considered as a class of important phosphorous an- alogues of depsipeptides. The coupling of $N$-protected amino acids and 1-hydroxyalkylphosphonates is a general method to prepare these compounds [58].

$(R)$-1-Amino-3-methylbutylphosphonic acid $((R)-204)$, a phosphonic L-Leu analogue, is a potent inhibitor of the metalloenzyme leucine aminopeptidase. Racemic dibenzyl 1-hydroxy-3- 
methylbutylphosphonate (203), an oxyanalog of phosphonic leucine, was partially debenzylated by the treatment with $\mathrm{NaI}$ to generate the corresponding monobenzyl ester 204. The ester 204 was resolved with (-)-ephedrine and then $O$-benzylated with $O$-benzyl- $N, N$-dicyclohexylurea (205) to give the $(R)-1$ hydroxy-3-methylbutylphosphonate $((R)-203)$. The latter was coupled with $N$-Boc-protected amino acids 206 to give the corresponding protected phosphonopeptides 207. After deprotection by hydrogenolysis and treatment with $\mathrm{CF}_{3} \mathrm{CO}_{2} \mathrm{H}$, the phosphonodepsipeptides 208 were obtained (Scheme 38) [59].

Phosphonodepsipeptides with C-1-hydroxyalkylphosphonic acids are also accessible through carbene insertion reactions. The reaction of the $N$-protected amino acids 209 and 210 with diethyl 1-diazo-2,2,2-trifluoroethylphosphonate (211) gave rise to the trifluoromethyl-containing phosphonodepsipeptides $\mathbf{2 1 2}$ and 213 with C-1-hydroxyalkylphosphonic acids in good yields under the catalysis of dirhodium tetraacetate (Scheme 39) $[60,61]$.

To develop novel bone-targeting prodrugs, a copper-catalyzed carbene insertion of tetraethyl diazomethyldiphosphonate (216) with $N$-Boc-protected amino acids 214 and 215 provided a simple method to synthesize phosphonodepsipeptides 217 and 218 containing a C-1-hydroxyalkylphosphonate motif in good yields (Scheme 40) [62].

The transition metal-catalyzed carbene insertion of 1-diazoalkylphononates and $N$-protected amino acids is an efficient and convenient method for the synthesis of phosphonodepsipeptides with C-1-hydroxyalkylphosphonic acids because the required 1-diazoalkylphononates can be readily prepared from the corresponding 1-aminoalkylphosphonates via nitrosation with amyl nitrite.

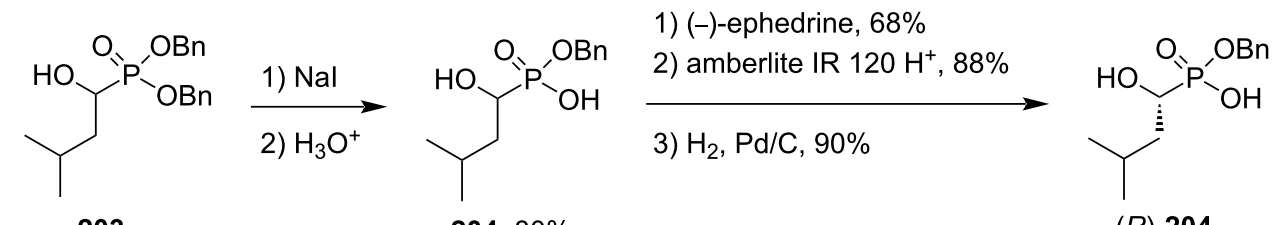

203

$20480 \%$

$(R)-204$<smiles>[B]P(=O)(O)[C@@H](O)CC(C)C</smiles>

$(R)-204$<smiles>CC(C)C[C@H](O)P(=O)(OCc1ccccc1)OCc1ccccc1</smiles>

(R)-203 $80 \%$

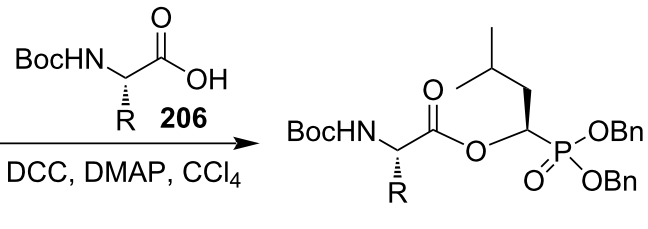

$20789-90 \%$

1) $\mathrm{H}_{2}, \mathrm{Pd} / \mathrm{C}, \mathrm{OEt}_{2}$

2) TFA<smiles>[R]C(N)C(=O)OC(CC(C)C)P(=O)(O)O</smiles>

$20880 \%$

Scheme 38: Synthesis of phosphonodepsipeptides with C-1-hydroxyalkylphosphonic acid.<smiles>O=C(O)NC(Cc1ccccc1)C(=O)O</smiles>

209<smiles>CC[C@H](C)C(NP)C(=O)O</smiles>

210<smiles>CCOP(=O)(OCC)C(=N)C(F)(F)F</smiles>

211

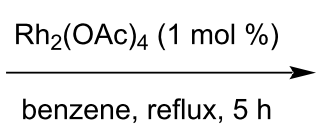

$\mathrm{Rh}_{2}(\mathrm{OAc})_{4}(1 \mathrm{~mol} \%)$

benzene, reflux, $5 \mathrm{~h}$<smiles>CCOP(=O)(OCC)C(OC(=O)C(Cc1ccccc1)NC(=O)OCc1ccccc1)C(F)(F)F</smiles>

$21269 \%$ 


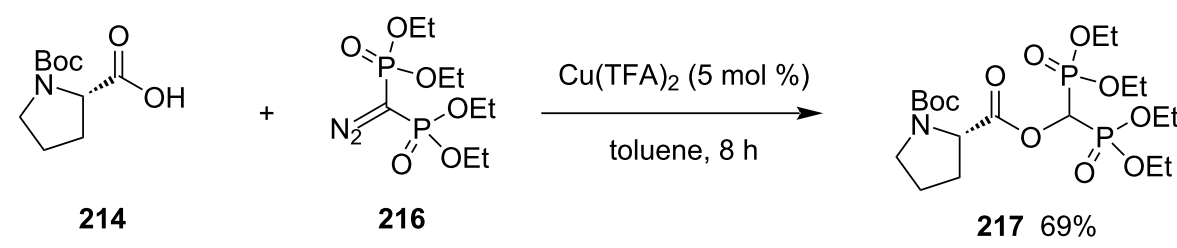<smiles>CC(C)C[C@H](N=C(O)c1ccccc1)C(=O)O</smiles>

215<smiles>CCOP(=O)(OCC)OC(=N)P(=O)(OCC)OCC</smiles>

216

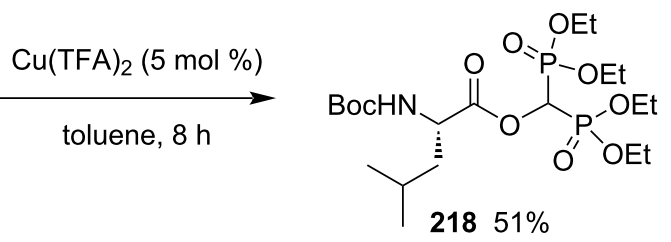

Scheme 40: Synthesis of phosphonodepsipeptides with a C-1-hydroxyalkylphosphonate motif via a copper-catalyzed carbene insertion reaction.

\section{Conclusion}

Phosphonodepsipeptides are phosphorus analogues of depsipeptides. They are more stable than the corresponding phosphonopeptides and have been widely used as enzyme inhibitors, haptens for the production of antibodies, biological agents, and prodrugs. Various synthetic methods of phosphonodepsipeptides have been developed, including the phosphonylation of hydroxy esters with phosphonochloridates or with phosphonic monoesters in the presence of coupling reagents, the alkylation of phosphonic monoesters with 1-(alkoxylcarbonyl)alkyl halides or sulfonates, the phosphinylation of hydroxy esters with phosphonochloridites and subsequent oxidation, and the Mannich-type condensation of amides, aldehydes, and dichlorophosphites followed by alcoholysis with hydroxy esters. Among the synthetic methods, the multicomponent Mannich-type condensation strategy shows a high efficiency, convergent feature, and product diversity. It can be expected that the convergent multicomponent condensation synthetic strategy will show wide applications in the preparation of biologically active phosphonodepsipeptides in the future. However, highly stereoselective asymmetric synthetic methods of phosphonodepsipeptides are of high demand and need to be developed in the near future.

\section{Funding}

The project was supported by the National Natural Science Foundation of China (Nos. 21772010 and 21572017).

\section{References}

1. Kafarski, P.; Lejczak, B. Synthesis of phosphono- and phosphinopeptides. In Aminophosphonic and Aminophosphinic Acids; Kukhar, V. P.; Hudson, H. R., Eds.; John Wiley \& Sons: West Sussex, England, 2000; pp 173-203.

2. Xu, J. Sci. Sin.: Chim. 2013, 43, 995-1004. doi:10.1360/032013-159
3. Drabowicz, J.; Kiełbasiński, P.; Łyżwa, P.; Mikołajczyk, M.; Zając, A. Product Class 15: Alkylphosphonic Acids and Derivatives. In Science of Synthesis; Mathey, F., Ed.; Georg Thieme Verlag KG: Stuttgart, Germany, 2009; Vol. 42, pp 679-778. doi:10.1055/sos-sd-042-00767

4. Xu, J. Phosphorus, Sulfur Silicon Relat. Elem. 2019, 194, 487-492. doi:10.1080/10426507.2018.1540481

5. Xu, J.; Xia, C.; Yu, L.; Zhou, Q. Phosphorus, Sulfur Silicon Relat. Elem. 1999, 152, 35-44. doi:10.1080/10426509908031615

6. Bartlett, P. A.; Vanmaele, L. J.; Kezer, W. B. Bull. Soc. Chim. Fr. 1986, 776-780.

7. Jia, C.; Yang, K.-W.; Liu, C.-C.; Feng, L.; Xiao, J.-M.; Zhou, L.-S.; Zhang, Y.-L. Bioorg. Med. Chem. Lett. 2012, 22, 482-484. doi:10.1016/j.bmcl.2011.10.094

8. Ortmann, R.; Wiesner, J.; Reichenberg, A.; Henschker, D.; Beck, E.; Jomaa, H.; Schlitzer, M. Arch. Pharm. (Weinheim, Ger.) 2005, 338, 305-314. doi:10.1002/ardp.200500976

9. Uh, E.; Jackson, E. R.; San Jose, G.; Maddox, M.; Lee, R. E.; Lee, R. E.; Boshoff, H. I.; Dowd, C. S. Bioorg. Med. Chem. Lett. 2011, 21, 6973-6976. doi:10.1016/j.bmcl.2011.09.123

10. Vercruysse-Moreira, K.; Déjugnat, C.; Etemad-Moghadam, G. Tetrahedron 2002, 58, 5651-5658. doi:10.1016/s0040-4020(02)00535-5

11. Smith, A. B., III; Taylor, C. M.; Benkovic, S. J.; Hirschmann, R. Tetrahedron Lett. 1994, 35, 6853-6856. doi:10.1016/0040-4039(94)85022-4

12. Isomura, S.; Ashley, J. A.; Wirsching, P.; Janda, K. D. Bioorg. Med. Chem. Lett. 2002, 12, 861-864. doi:10.1016/s0960-894x(02)00047-1

13. Ortmann, R.; Wiesner, J.; Reichenberg, A.; Henschker, D.; Beck, E.; Jomaa, H.; Schlitzer, M. Bioorg. Med. Chem. Lett. 2003, 13, 2163-2166. doi:10.1016/s0960-894x(03)00354-8

14. Ntatsopoulos, V.; Macegoniuk, K.; Mucha, A.; Vassiliou, S.; Berlicki, Ł. Eur. J. Med. Chem. 2018, 159, 307-316. doi:10.1016/j.ejmech.2018.09.074

15. Montenegro, I. P. F. M.; Mucha, A. P.; Reis, I.; Rodrigues, P.; Almeida, C. M. R. Int. J. Environ. Sci. Technol. 2017, 14, 943-955. doi:10.1007/s13762-016-1215-9 
16. Skinner-Adams, T. S.; Lowther, J.; Teuscher, F.; Stack, C. M.; Grembecka, J.; Mucha, A.; Kafarski, P.; Trenholme, K. R.; Dalton, J. P.; Gardiner, D. L. J. Med. Chem. 2007, 50, 6024-6031. doi:10.1021/jm070733v

17. Carramiñana, V.; Ochoa de Retana, A. M.; Palacios, F.; de los Santos, J. M. Molecules 2020, 25, 3332. doi:10.3390/molecules25153332

18. Mucha, A.; Kafarski, P.; Berlicki, Ł. J. Med. Chem. 2011, 54, 5955-5980. doi:10.1021/jm200587f

19. Giannousis, P. P.; Bartlett, P. A. J. Med. Chem. 1987, 30, 1603-1609. doi:10.1021/jm00392a014

20. Song, J.-B.; Hah, S.-S.; Suh, J.-H. Bull. Korean Chem. Soc. 2004, 25, 1703-1706. doi:10.5012/bkcs.2004.25.11.1703

21. Yang, K.-W.; Brandt, J. J.; Chatwood, L. L.; Crowder, M. W. Bioorg. Med. Chem. Lett. 2000, 10, 1085-1087. doi:10.1016/s0960-894x(00)00186-4

22. Chang, Y.-P.; Tseng, M.-J.; Chu, Y.-H. Anal. Biochem. 2006, 359, 63-71. doi:10.1016/j.ab.2006.08.009

23. Hoffmann, M. Aust. J. Chem. 1988, 41, 605-607. doi:10.1071/ch9880605

24. Inami, K.; Teshima, T.; Miyashita, H.; Shiba, T. Bull. Chem. Soc. Jpn. 1995, 68, 942-949. doi:10.1246/bcsj.68.942

25. Sampson, N. S.; Bartlett, P. A. J. Org. Chem. 1988, 53, 4500-4503. doi:10.1021/jo00254a015

26. Bartlett, P. A.; Giangiordano, M. A. J. Org. Chem. 1996, 61, 3433-3438. doi:10.1021/j0952074c

27. Shih, H.-W.; Chen, K.-T.; Chen, S.-K.; Huang, C.-Y.; Cheng, T.-J. R.; Ma, C.; Wong, C.-H.; Cheng, W.-C. Org. Biomol. Chem. 2010, 8, 2586-2593. doi:10.1039/c000622j

28. Malachowski, W. P.; Coward, J. K. J. Org. Chem. 1994, 59, 7625-7634. doi:10.1021/jo00104a017

29. Tsukamoto, T.; Haile, W. H.; McGuire, J. J.; Coward, J. K. Arch. Biochem. Biophys. 1998, 355, 109-118. doi:10.1006/abbi.1998.0703

30. Han, L.; Hiratake, J.; Kamiyama, A.; Sakata, K. Biochemistry 2007, 46, 1432-1447. doi:10.1021/bi061890j

31. Nakajima, M.; Watanabe, B.; Han, L.; Shimizu, B.-i.; Wada, K.; Fukuyama, K.; Suzuki, H.; Hiratake, J. Bioorg. Med. Chem. 2014, 22 , 1176-1194. doi:10.1016/j.bmc.2013.12.034

32. Karanewsky, D. S.; Badia, M. C. Tetrahedron Lett. 1986, 27 , 1751-1754. doi:10.1016/s0040-4039(00)84364-6

33. Campagne, J.-M.; Coste, J.; Jouin, P. Tetrahedron Lett. 1993, 34 , 6743-6744. doi:10.1016/s0040-4039(00)61690-8

34. Campagne, J.-M.; Coste, J.; Jouin, P. J. Org. Chem. 1995, 60, 5214-5223. doi:10.1021/jo00121a045

35. Galéotti, N.; Coste, J.; Bedos, P.; Jouin, P. Tetrahedron Lett. 1996, 37, 3997-3998. doi:10.1016/0040-4039(96)00742-3

36. Gobec, S.; Urleb, U. Molecules 2002, 7, 394-404. doi:10.3390/70400394

37. Pícha, J.; Buděšínský, M.; Šanda, M.; Jiráček, J. Tetrahedron Lett. 2008, 49, 4366-4368. doi:10.1016/j.tetlet.2008.05.028

38. Pícha, J.; Buděšínský, M.; Hančlová, I.; Šanda, M.; Fiedler, P.; Vaněk, V.; Jiráček, J. Tetrahedron 2009, 65, 6090-6103. doi:10.1016/j.tet.2009.05.051

39. Campbell, D. A. J. Org. Chem. 1992, 57, 6331-6335. doi:10.1021/jo00049a051

40. Yuan, C.; Wang, G. Phosphorus, Sulfur Silicon Relat. Elem. 1992, 71, 207-212. doi:10.1080/10426509208034513

41. Xu, J.; Fu, N. Synth. Commun. 2000, 30, 4137-4145. doi:10.1080/00397910008087030
42. Fu, N.; Zhang, Q.; Duan, L.; Xu, J. J. Pept. Sci. 2006, 12, 303-309. doi:10.1002/psc.727

43. Xu, J.; Fu, N. J. Chem. Soc., Perkin Trans. 1 2001, 1223-1226. doi:10.1039/b008340m

44. Xu, J.; Wei, M. Synth. Commun. 2001, 31, 1489-1497. doi:10.1081/scc-100104060

45. Li, B.; Cai, S.; Du, D.-M.; Xu, J. Org. Lett. 2007, 9, 2257-2260. doi:10.1021/ol070360s

46. Meng, F.; Xu, J. Amino Acids 2010, 39, 533-538. doi:10.1007/s00726-009-0469-7

47. Meng, F.; Xu, J. Tetrahedron 2013, 69, 4944-4952. doi:10.1016/j.tet.2013.04.032

48. He, F.; Meng, F.; Song, X.; Hu, W.; Xu, J. Org. Lett. 2009, 11, 3922-3925. doi:10.1021/ol901543y

49. Meng, F.; He, F.; Song, X.; Zhang, L.; Hu, W.; Liu, G.; Xu, J. Amino Acids 2012, 43, 423-429. doi:10.1007/s00726-011-1098-5

50. Liu, H.; Cai, S.; Xu, J. J. Pept. Sci. 2006, 12, 337-340. doi:10.1002/psc.731

51. Xu, J.; Gao, Y. Synthesis 2006, 783-788. doi:10.1055/s-2006-926324

52. Fang, Z.; Yang, H.; Miao, Z.; Chen, R. Helv. Chim. Acta 2011, 94, 1586-1593. doi:10.1002/hlca.201100025

53. Skwarczyński, M.; Kafarski, P. Synth. Commun. 1995, 25, 3565-3571. doi:10.1080/00397919508015491

54. Meyer, J. H.; Bartlett, P. A. J. Am. Chem. Soc. 1998, 120, 4600-4609. doi:10.1021/ja973715j

55. de Fatima Fernandez, M.; Vlaar, C. P.; Fan, H.; Liu, Y.-H.; Fronczek, F. R.; Hammer, R. P. J. Org. Chem. 1995, 60, 7390-7391. doi:10.1021/jo00128a006

56. Vercruysse, K.; Déjugnat, C.; Munoz, A.; Etemad-Moghadam, G. Eur. J. Org. Chem. 2000, 281-289. doi:10.1002/(sici)1099-0690(200001)2000:2<281::aid-ejoc281>3.0.co;2 $-2$

57. Déjugnat, C.; Etemad-Moghadam, G.; Rico-Lattes, I. Chem. Commun. 2003, 1858-1859. doi:10.1039/b304420c

58. Yang, J. Q.; Yang, X.; Zeng, F. K.; Li, P. Preparation method of phosphonate derivative containing amino acid fragments and antineoplastic application. Chinese Pat. CN105503947A, April 20, 2016.

59. Hoffmann, M. J. Prakt. Chem. 1990, 332, 251-255. doi:10.1002/prac.19903320217

60. Titanyuk, I. D.; Vorob'eva, D. V.; Osipov, S. N.; Beletskaya, I. P. Synlett 2006, 1355-1358. doi:10.1055/s-2006-939704

61. Titanyuk, I. D.; Vorob'eva, D. V.; Osipov, S. N.; Beletskaya, I. P. Russ. J. Org. Chem. 2010, 46, 619-623. doi:10.1134/s1070428010050015

62. Wang, X.; Zhang, C.; Ma, Q.; Xiao, W.; Guo, L.; Wu, Y. Tetrahedron Lett. 2018, 59, 280-283. doi:10.1016/j.tetlet.2017.12.038 


\section{License and Terms}

This is an Open Access article under the terms of the Creative Commons Attribution License (https://creativecommons.org/licenses/by/4.0). Please note that the reuse, redistribution and reproduction in particular requires that the author(s) and source are credited and that individual graphics may be subject to special legal provisions.

The license is subject to the Beilstein Journal of Organic Chemistry terms and conditions:

(https://www.beilstein-journals.org/bjoc/terms)

The definitive version of this article is the electronic one which can be found at:

https://doi.org/10.3762/bjoc.17.41 